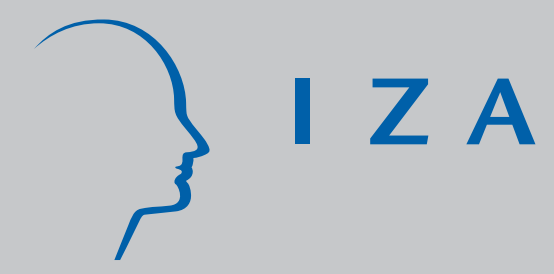

IZA DP No. 2591

The Part-Time Wage Penalty in European

Countries: How Large Is It for Men?

Síle O' Dorchai

Robert Plasman

François Rycx

J anuary 2007 


\title{
The Part-Time Wage Penalty in European Countries: How Large Is It for Men?
}

\author{
Síle O'Dorchai \\ Université Libre de Bruxelles, DULBEA \\ Robert Plasman \\ Université Libre de Bruxelles, DULBEA \\ François Rycx \\ Université Libre de Bruxelles, DULBEA \\ and IZA
}

Discussion Paper No. 2591
January 2007

IZA

P.O. Box 7240

53072 Bonn

Germany

Phone: +49-228-3894-0

Fax: +49-228-3894-180

E-mail: iza@iza.org

\begin{abstract}
Any opinions expressed here are those of the author(s) and not those of the institute. Research disseminated by IZA may include views on policy, but the institute itself takes no institutional policy positions.

The Institute for the Study of Labor (IZA) in Bonn is a local and virtual international research center and a place of communication between science, politics and business. IZA is an independent nonprofit company supported by Deutsche Post World Net. The center is associated with the University of Bonn and offers a stimulating research environment through its research networks, research support, and visitors and doctoral programs. IZA engages in (i) original and internationally competitive research in all fields of labor economics, (ii) development of policy concepts, and (iii) dissemination of research results and concepts to the interested public.
\end{abstract}

IZA Discussion Papers often represent preliminary work and are circulated to encourage discussion. Citation of such a paper should account for its provisional character. A revised version may be available directly from the author. 


\section{ABSTRACT}

\section{The Part-Time Wage Penalty in European Countries: How Large Is It for Men?*}

Economic theory advances a number of reasons for the existence of a wage gap between part-time and full-time workers. Empirical work has concentrated on the wage effects of parttime work for women. For men, much less empirical evidence exists, mainly because of lacking data. In this paper, we take advantage of access to unique harmonised matched employer-employee data (i.e. the 1995 European Structure of Earnings Survey) to investigate the magnitude and sources of the part-time wage penalty for male workers in six European countries (i.e. Belgium, Denmark, Ireland, Italy, Spain, and the UK). Findings show that the raw gap in hourly gross pay amounts to 16 per cent of male part-timer's wage in Spain, to 24 per cent in Belgium, to 28 per cent in Denmark and Italy, to 67 per cent in the UK and to 149 per cent in Ireland. Human capital differences explain between 31 per cent of the observed wage gap in the UK and 71 per cent in Denmark. When a larger set of control variables is taken into account (including occupation, industry, firm size, and level of wage bargaining), a much smaller part of the gap remains unexplained by differences in observed characteristics (except in Italy). Overall, results suggest that policy initiatives to promote lifelong learning and training are of great importance to help part-timers catch up. Moreover, except for Italy, they point to a persisting problem of occupational and sectoral segregation between men working part-time and full-time which requires renewed policy attention.

JEL Classification: $\quad \mathrm{C} 13, \mathrm{C} 31, \mathrm{~J} 24, \mathrm{J31}, \mathrm{J} 71$

Keywords: $\quad$ work status, part-time employment, wage gap, decomposition, human capital, segregation

Corresponding author:

François Rycx

Université Libre de Bruxelles

CP 140 - Av. F. D. Roosevelt 50

B-1050 Brussels

Belgium

E-mail: frycx@ulb.ac.be

\footnotetext{
* This paper is produced as part of a Targeted Socio-Economic Research (TSER) project on Pay Inequalities and Economic Performance (PiEP) financed by the European Commission (Contract nr. HPSE-CT-1999-00040). The data used in this study come from the 1995 European Structure of Earnings Survey. Unfortunately, due to confidentiality issues, this data set is only available for members of the PiEP research project (http://cep.Ise.ac.uk/piep/).
} 


\section{Introduction}

Economic theory advances a number of reasons for the existence of a wage gap between parttime and full-time workers: labour supply and demand interactions (e.g. Ermish and Wright, 1991; Shepard et al., 1996; Rose 1998); arguments related to the cost structure of firms (e.g. Montgomery, 1988; Hamermesh and Rees, 1993; Lindbeck and Snower, 2000); productivityrelated factors (e.g. Barzel, 1973; Moffitt, 1984; Tummers and Woittiez, 1991); and wage implications of the institutional settings in a specific region or country (e.g. Riley, 1997; Vella and Verbeek, 1998; Koskela and Vilmunen, 1996). Empirical work has mainly concerned women's part-time work and the negative wage effects of working reduced hours. This relative preference for women is due to several factors: the overrepresentation of women in part-time work, the feminised nature of the work/family reconciliation debate, and consequently the lack of observations for men making statistical inference difficult. Recent analyses of the part-time wage gap for women are those of Bardasi and Gornick (2000, 2002), Jepsen (2001), Jepsen et al. (2005), Hu and Tijdens (2003), Rodgers (2004), Manning and Petrongolo (2005) and Hardoy and Schøne (2006). A negative wage gap is systematically observed for women deciding to work part-time but its magnitude differs substantially across the different studies treating different countries. Controlling for differences in characteristics (especially occupation) or for self-selection completely eliminates the wage gap in Norway (Hardoy and Schøne, 2006), Australia (Rodgers, 2004) and Belgium (Jepsen, 2001; Jepsen et al., 2005). In the other studies, a wage gap remains and this unexplained part also shows considerable cross-country variation.

A separate analysis of male and female part-timers is warranted given that both the wage determination process and the factors that influence (constrain) the choice of employment status are different for men and women. While childcare issues are women's most important stated reason for being in part-time employment, men's is their pursuit of educational qualifications ${ }^{1}$. Furthermore, being unable to find a full-time job is much more often stated as a reason for working reduced hours by men. The part-time workforce is thus a multi-faceted group of workers, male and female part-timers belonging to two very different labour market realities.

Studies into male part-time work and its wage effects are much less numerous and obviously concern those countries where men's presence in part-time jobs is the highest, such as the Netherlands (Russo and Hassink, 2005) - as a European example - but also Australia (Booth and Wood, 2004; Rodgers 2004) and the US (Ferber and Waldfogel, 1998; Hirsch, 2005).

\footnotetext{
${ }^{1}$ European Foundation for the Improvement of Living and Working Conditions (2005).
} 
This empirical work provides less systematic evidence for the existence of a negative wage gap. As already mentioned, an important reason for this lack of empirical studies on the parttime wage penalty for men is that in most countries men only make up a very small proportion of the part-time work force and thus most data bases contain too little observations on male part-timers for statistical studies to yield significant results. It is precisely with respect to this shortcoming that the present paper can contribute to the existing literature. Indeed, the underlying analysis of the part-time wage penalty for men is based on the European Structure of Earnings Survey (ESES), an employer-employee matched data base that is well suited for this type of research. It provides harmonised information - provided by the establishments' management - on large numbers of both establishments (e.g. sector of activity, size of the firm, and level of wage bargaining) and employees (e.g. age, education, gross hourly wage, sex, and occupation) of the private sector in six European countries.

The main question this paper attempts to respond to is how part-time work affects men's wage in Belgium, Denmark, Ireland, Italy, Spain, and the United Kingdom. Not only do we compute the size of the part-time/full-time wage gap but we also decompose the gap to determine which part of it can be attributed to differences in human capital between part- and full-timers. The gap that remains after controlling for human capital gives an idea of the extent of "market-wide" wage disparity between both groups of workers. By further adding, inter alia, occupation and sector-related information to the regressions - without ignoring the fact that these variables are endogenous - a more precise measure of the wage gap within a sector or occupation is obtained.

This paper provides new insight into the thus far almost unexplored world of male part-time work. Not only has male part-time work been given only limited research attention, we are not aware of a single study that presents cross-country evidence regarding the issue.

The remainder of this paper is organised as follows. Section 2 presents the theoretical framework for our study and illustrates it with existing empirical work. In section 3 the estimation procedure is explained whereas the data and the set of regression variables are presented in section 4. Descriptive statistics are summarised in section 5. Section 6 is devoted to the most important findings that came out of the wage equation estimations, the wage gap computations and the decomposition of the gaps. Finally, in section 7 we conclude. 


\section{Review of the literature}

\subsection{Theoretical background}

Economic theory advances several possible explanations for the difference in hourly pay of part-time and full-time workers. These reasons for a wage differential can be grouped into four main clusters which are not mutually exclusive but rather tend to overlap and reinforce each other.

The first cluster of reasons pertains to labour supply, the argument being that some categories of persons prefer to work part-time rather than full-time (and vice versa). This is particularly stated to be the case with regard to young workers (students), parents with heavy home responsibilities and older workers, all of whom may be seen to have a preference for part-time employment and for this reason accept wages lower than for full-time employment. However, differences in preferences for part-time employment are not enough to generate a part-time wage penalty. In order for this to occur workers must be heterogeneous and it cannot be that employers are indifferent to the way they schedule work hours among workers. Hence a mix of workers' preferences, skill differences and employer preferences can generate a part-time wage penalty. However, these same forces may also work in the opposite direction. Flexible working hours and other alternatives to the traditional full-time work schedule have been shown to increase productivity and consequently also wages (McGuire and Liro, 1986; Hagemann, 1994; Shepard et al., 1996; Rose, 1998). A part-time wage premium is typically observed in industries that face seasonal or fluctuating demand for or supply of their output that cannot be managed through the carrying of inventories; employers then consent to pay high wages during peak periods when productivity is high to part-time workers willing to work short intensive shifts. Hence, if a firm has a particularly high labour demand during short intervals of time, and workers prefer to work long hours at a stretch rather than space out this working time, then part-time wages could exceed full-time wages, as there is not enough labour supply to meet labour demand. A lack of geographical mobility may also contribute to the part-time/full-time wage gap. Ermisch and Wright (1991) state that parttimers are more strongly bound by spatial constraints because they are less willing to pay high costs to commute to and from work given that they are often just secondary breadwinners in the household. Given this lack of labour supply elasticity, the local labour market is in the hands of firms practising monopsonistic power. Led by their rationality as profit-maximising economic agents, they tend to adjust part-time wages downwards.

The second cluster concerns the cost structure of firms. The existence of fixed costs including the administrative costs of maintaining records for each employee, recruitment and firing costs and any components of fringe benefits that are independent of hours worked - 
mean that a firm's total labour costs do not increase proportionally with hours worked (Montgomery, 1988; Oi, 1962). As a result, part-time workers are relatively more costly to firms and therefore receive lower wages. Moreover, Hamermesh and Rees (1993) have shown that fixed costs tend to be positively related to the level of skills. This second element explains why part-time work is likely to induce a larger wage penalty among high-skilled workers. Furthermore, given firms' profit-maximising behaviour, employers tend to have a clear preference for holistic or all-encompassing jobs (as opposed to the tayloristic jobs of the previous generation which relied on a high degree of specialisation within the workforce), for versatile tasks in close accordance with changing requirements on the demand side, for job rotation schemes broadening workers' overall employability throughout the whole firm, and finally, following the same logic, for multi-task jobs requiring diverse skills. An efficient work organisation based on such types of job can be successful only when the workforce acquires the necessary firm-specific human capital through appropriate training courses. Hence, in addition to recruitment costs, these training costs make part-time workers relatively more expensive for firms which react by paying them lower wages (Lindbeck and Snower, 2000).

The third cluster of factors that can account for a part-time wage penalty is related to the productivity of the worker. Several theories relate productivity to number of hours of work. An argument in one direction is that, due to start-up effects, productivity rises slowly at the beginning of a working day. As a result, the worker's productivity during the last hour of work is above the average daily level of productivity (Barzel, 1973). Hence, part-time workers who work less hours are less productive and therefore paid lower wages. However, Moffitt (1984) and Tummers and Woittiez (1991) have contested this model for the development of productivity during the day. Indeed, they have shown that part-time avoids the negative 'fatigue' effect which causes marginal productivity to drop in case of long working hours or overtime. Given that average productivity is shown to peak at 34 working hours a week, part-timers are more productive than are their full-time colleagues and should be paid accordingly.

The fourth cluster of issues is related to the institutional settings in a specific region or country. Several studies have shown that part-timers have a lower level of union membership (Riley, 1997). In a theoretical paper by Skåtun (1998), the higher demand for part-timers is explained by the individual bargaining process that allows the firm to increase the surplus from the bargain. Hence, part-timers are paid less as they have less power. Vella and Verbeek (1998) find that people with characteristics that give them lower wages are given higher union premiums, but Main and Reilly (1992) report equal mark-ups for women (full-time or parttime) and men. Be it as it may, if part-timers are less likely to be members of a union and furthermore often have characteristics that give them lower wages, then the wage effect of 
part-time risks being double. Furthermore, given the progressive tax structure in some countries, part-timers, who by definition earn a lower annual gross wage than full-timers, are taxed less and therefore union bargaining will often lead to a lower hourly gross wage for part-timers than for full-timers (Koskela and Vilmunen, 1996). This is the effect of unions tending to reason in terms of net wages. Indeed, unions will be less likely to push as hard for higher gross wages for part-timers than for full-timers as the former face a lower average tax rate. Also, the composition of income and payroll taxes may influence the wage difference between full-time and part-time workers (Koskela and Schöb, 1999). However, the taxation and payroll system is also found to decrease the wage rate with the number of hours worked. Vella (1993) argues that the "true" wage is held constant but that the hourly wage rate decreases and is replaced by fringe benefits which are not taxable. Finally, anti-discrimination legislation may also have a decisive effect on the existence or not of a pay penalty.

\subsection{Empirical background}

Obviously, most empirical studies concern those countries with a share of male part-timers worth mentioning. Within the EU-15, the only country to fall into this category is the Netherlands ${ }^{2}$. Outside the EU-15, recent studies exist for Australia which tops the OECD league in terms of its proportion of working men who are part-time, 17\% in 2003 (Booth and Wood, 2004) and the US where more than one third of part-time work is undertaken by men (in 2005, 10.7\% of all employed men worked part-time whereas just $25.2 \%$ of all employed women did so (U.S. Department of Labor, 2006)).

Russo and Hassink (2005) have examined the Dutch part-time wage penalty from a career perspective. Part-time employment spells negatively affect workers' careers and consequently also their relative wages when firms base promotions on acquired skills and accumulated human capital, when firms' work incentive schemes are based on performance measures that rely on the number of hours worked or, finally, when workers are screened according to the number of hours worked. They find that promotions account for a wage growth of eight log points and thus, given the lower incidence of promotion among part-time workers, their wages grow more slowly so that a wage gap develops over time between part-time and full-time workers (no wage gap is found at the onset of a career but only as the effect of missed promotions grows stronger). Russo and Hassink (2005) find the part-time wage penalty to be larger for male than for female workers. Male (female) workers in small part-time jobs (less than 20 hours per week) suffer a wage penalty of about $9.2 \%$ (2.4\%) in comparison with their full-time male (female) colleagues. Male (female) workers in part-time employment (20 hours

\footnotetext{
${ }^{2}$ As far as we know, no empirical work exists for Norway although $13.8 \%$ of all employed men worked parttime in 2005 (Eurostat, 2005).
} 
or more but less than 36 hours per week) suffer a wage penalty of $6.3 \%$ (1.7\%). Russo and Hassink (2005) offer two explanations for this. Firstly, female workers switch more often between part-time and full-time jobs and are thus more likely to spend at least some of their time on the labour market in full-time employment. In contrast, male workers tend to be stuck in one form of employment with little opportunity for change. In this scenario the female parttime wage penalty should turn out to be smaller than the male part-time wage penalty, even if both have the same promotion probabilities. The second explanation relies on the different salience of part-time employment among male and female workers. If most women hold parttime jobs (and Dutch women are encouraged to do so), part-time employment status cannot be used as a screening device because it ceases to be informative about work attitudes. On the contrary, because part-time employment is still rather uncommon among male workers, it becomes salient when chosen by male workers and can therefore be used as a screening device. If male part-time workers are adversely affected by firms' screening behaviour (but female part-time workers are not), it follows that male workers should be characterised by a larger part-time wage penalty relative to female workers.

Booth and Wood (2004) have studied part-time wages in Australia and find that the usual negative part-time wage penalty found in other countries is not found in Australia once unobserved individual heterogeneity has been taken into account. Instead, part-time men and women typically earn an hourly pay premium of between 13 and 15 log points over and above comparable full-time workers, once other observable and unobservable characteristics are accounted for ${ }^{3}$.

However, Rodgers (2004) found no evidence of a part-time wage penalty/premium for either men or women in Australia. Her results indicate that the unadjusted part-time wage penalty amounting to 21 per cent for men (statistically significant) and 7 per cent for women (not statistically significant) can be explained by selection into full-time or part-time employment and controls for human capital and type of job. No statistically significant adjusted wage differentials remain.

Ferber and Waldfogel (1998) have examined the long-term consequences of non-traditional employment among men and women in the US. The authors use data from the National Longitudinal Survey of Youth (NLSY). The NLSY provides complete work histories with detailed information about respondents' past and present jobs over a 15-year span, 19791993. The data are used to observe whether respondents are currently in non-traditional jobs, to track whether they have ever been in such jobs, and to follow those who switch to or from

\footnotetext{
${ }^{3}$ These figures correspond to fixed effects estimates. Random effects estimates suggest the part-time wage premium to range from approximately 3 to $6 \%$ for women and from 3 to $7 \%$ for men.
} 
these jobs. They find that after controlling for demographic and human-capital variables, men who are working part-time, particularly those who are voluntarily working part-time, have much lower hourly wages than men in traditional jobs and the average pay penalty is much more pronounced than for women. For both men and women, having a non-traditional employment history is associated with lower current wages and benefits, even after controlling for current employment type, with one exception: no significant wage effect is found for women who voluntarily worked part-time in the past. The return to part-time experience (voluntary and involuntary) is basically zero for men, while for women, the return is about half as large as the return to non-part-time experience. The greater negative impact on men than on women of currently working part time - particularly voluntarily - is consistent with the hypothesis that employers may be more likely to judge men in part-time employment unfavourably because their careers do not conform to expectations. The results of the wage growth models further suggest that men working part-time voluntarily may have negative attributes (such as less ability or motivation) that are not measured in the data, while the opposite is true for women. Finally, it is entirely possible that low wages cause men to work fewer hours, rather than vice versa, while there is evidence to the contrary for women.

Hirsch (2005) also examined the part-time/full-time wage gap among men and women in the US. His study is based on the Current Population Survey (CPS) earnings files for January 1989 through December 1997. He stresses the importance of interpreting with care the raw figures: overall, women in part-time jobs are found to earn $25.9 \%$ less than women in fulltime jobs, while the comparable figure is $46.2 \%$ for men. If it is the case that part-time jobs require less worker skills than full-time jobs, then the alleged wage gap is an illusion. In other words, what should be of interest is the residual wage gap that remains after having controlled for differences between part-time and full-time workers in measurable personal, human capital, location, industry and occupational characteristics. He finds that roughly two-thirds of the part-time wage disadvantage for women and men can be accounted for by measurable differences in workers and jobs. Much of the remaining differential reflects unmeasured worker-specific skills and tastes, as captured through longitudinal analysis that measures wage changes among individual workers switching from part-time to full-time employment, or vice versa. Longitudinal estimates indicate little if any part-time penalty for women and a modest penalty among men.

In sum, in the US, men suffer larger wage penalties from past and current part-time employment spells but the more controls are added to the wage equations, the smaller the remaining wage differential.

An early study for Canada, carried out in 1986 by Simpson and reported in Rodgers (2004), showed a difference in gross wages between full-timers and part-timers of $31 \%$, a gap that 
was shown to rise to $43 \%$ when just male workers were considered. However, after adjusting for the selectivity bias, a wage penalty of $10 \%$ was found for Canadian part-time workers. He found this penalty to be smaller for married women (3\%) and men (5\%) than for single women (18\%).

As mentioned before, we are not aware of the existence of any recent evidence on the wage effect of working part-time for men in other countries.

\section{Estimation approaches}

The purpose of this analysis is to measure the main reasons for the difference in the gross hourly wage rate for similarly skilled men working in otherwise similar part-time and fulltime jobs. To achieve this we use a straightforward estimation method. Semi-logged wage equations are estimated for part-time (pt) and full-time (ft) workers:

$\log \left(w_{p t}\right)=\beta_{\mathrm{pt}} \mathrm{X}_{\mathrm{pt}}+\gamma_{\mathrm{pt}} \mathrm{Z}_{\mathrm{pt}}+\varepsilon_{\mathrm{pt}}$
$\log \left(w_{\mathrm{ft}}\right)=\beta_{\mathrm{ft}} \mathrm{X}_{\mathrm{ft}}+\gamma_{\mathrm{ft}} \mathrm{Z}_{\mathrm{pt}}+\varepsilon_{\mathrm{ft}}$

The dependent variable (log $\left(w_{p t}\right)$ for part-time and $\log \left(w_{f t}\right)$ for full-time jobs) is the log of gross hourly wages.

The explanatory or independent variables on the right-hand side of the equations that are captured by the vectors $\mathrm{X}_{\mathrm{pt}}$ for part-time and $\mathrm{X}_{\mathrm{ft}}$ for full-time jobs respectively include only human capital indicators such as level of education (measured by 6 categories ranging from primary to post-graduate education), prior potential experience based on the formula 'age - 6 - years of education - seniority', its square and its cube and tenure, its square and its cube.

The vectors $Z_{p t}$ for part-time and $Z_{f t}$ for full-time jobs respectively include a dummy indicating whether the individual supervises other workers or not, 20 occupational dummies corresponding to the second level of the International Standard Classification of Occupations (ISCO-88), 42 industry dummies corresponding to the 2-digit NACE-codes, regional dummies (except for Denmark and Ireland), dummies relative to the type of economic and financial control of the establishments (fully state-owned, mainly state-owned, private or other), dummies capturing the level of collective bargaining, contract type, establishment size and finally, dummies to indicate whether premia were received to compensate for overtime or shift work, night work and/or weekend work. $\varepsilon_{\mathrm{pt}}$ and $\varepsilon_{\mathrm{ft}}$ are the usual errors terms. 
The econometric work is focused on the wage gap between men working part-time and fulltime using two different specifications. Firstly, we estimated wage equations controlling only for human capital indicators (X). Secondly, a part-time and a full-time wage regression are estimated with gross hourly wage as the dependent variable and including the widest possible range of independent variables ( $\mathrm{X}$ and $\mathrm{Z}$ ). The distinction between the first and the second case is interesting for the following reason. In the first case we evaluate the extent to which the wage effect of part-time work is due to different investments in human capital. In other words, we evaluate wage disparities between part- and full-time workers "market-wide”. In the second case, we include other control variables (such as occupation, sector, size of the establishment, etc.) to asses which part of the observed wage gap remains. In other words, we assume that human capital theory is not sufficient to explain the part-time/full-time wage differential. Indeed, equal attainments in terms of education and experience yield a different wage according to the type of occupation, the economic sector, the size of the establishment, the level of collective bargaining, etc.

To estimate these wage equations we used standard OLS with White (1980) heteroscedasticity consistent standard errors, well aware of the potential bias of our estimates since the models do not account for systematic selection of workers into part-time and full-time employment (Rodgers, 2004; Hardoy and Schøne, 2006). To do so, it would have been necessary to apply a two-stage Heckman (1979) procedure. However, the dataset used in the present study does not contain the necessary supply-side variables to estimate the probability of working parttime such as household size, age of children and marital status. So standard OLS estimates are computed for each individual conditional upon his/her working hours. We do not believe this to be a major weakness given that the interest of this analysis lies in the size of the dataset as well as in the richness of explanatory variables introduced in the wage equations as compared to existing empirical evidence. Moreover, there still remain many methodological problems linked to the identification of the Heckman (1979) procedure (Manski, 1995; Vella, 1998).

Once the wage equations were estimated, the Oaxaca (1973) and Blinder (1973) procedure was applied in order to decompose the wage differential into a price effect and a characteristics effect. Full-time employment is set as the reference category.

$$
\overline{\log \left(\mathrm{w}_{\mathrm{ft}}\right)}-\overline{\log \left(\mathrm{w}_{\mathrm{pt}}\right)}=\left(\bar{Y}_{f t}-\bar{Y}_{p t}\right) \hat{\beta}_{f t}+\bar{Y}_{p t}\left(\hat{\beta}_{f t}-\hat{\beta}_{p t}\right)
$$

where the indices $\mathrm{ft}$ and pt refer to full-time and part-time workers respectively, $\overline{\log (\mathrm{w})}$ represents the average of the $\log$ gross hourly wage, and $\bar{Y}$ is a vector containing the mean values of the explanatory variables (human capital characteristics only or combined with other individual and establishment variables). The first term on the right-hand side of the 
equation sign represents the share of the part-time/full-time wage gap that is due to differences in observable characteristics between part-time and full-time workers. In other words, if both part-time and full-time workers were remunerated as in the reference case (fulltime), how do their differing characteristics affect their respective wage rates? The second term measures the part of the wage gap explained by differences in the returns to observable characteristics. To put it differently, how much does a person with part-time characteristics gain from being employed in a full-time rather than in a part-time job? This term is often referred to as the discrimination component or the price effect.

Since we are interested in evaluating the absolute wage gap between part-time and full-time workers, the logged hourly wages and wage differential should be transformed into monetary terms. To do this, the methodology recommended by Stewart (1983) and Rodgers (2004) is applied. We use the exponential function to rewrite the difference in predicted mean log hourly wages in monetary terms

The wage difference:

$\overline{\log \left(\mathrm{w}_{\mathrm{ft}}\right)}-\overline{\log \left(\mathrm{w}_{\mathrm{pt}}\right)}=\hat{\beta}_{\mathrm{ft}} \bar{Y}_{\mathrm{ft}}-\hat{\beta}_{\mathrm{pt}} \overline{\mathrm{Y}}_{\mathrm{pt}}=\hat{\gamma}$

is re-expressed as :

$\overline{\mathrm{w}_{\mathrm{ft}}} / \overline{\mathrm{w}_{\mathrm{pt}}}=\exp (\hat{\gamma})$

We can then easily rewrite the full-time/part-time wage gap we are interested in as:

$\left.\overline{\left(\mathrm{w}_{\mathrm{ft}}\right.}-\overline{\mathrm{w}_{\mathrm{pt}}}\right) / \overline{\mathrm{w}_{\mathrm{pt}}}=\exp (\hat{\gamma})-1$

\section{Data and variables}

The present study is based on the 1995 wave of the European Structure of Earnings Survey (ESES), carried out by Eurostat. It is a survey that covers six European countries and that provides a wealth of harmonised information, provided by establishments' management, regarding both the establishments (e.g. economic sector, size of the workforce, level of collective bargaining, region of establishment) and the employees (e.g. age, level of education, tenure, gross earnings, paid hours of work, sex, occupation, wage bonuses). It represents all establishments with at least ten workers and with economic activities falling within sections $\mathrm{C}$ to $\mathrm{K}$ of the Nace Rev. 1 nomenclature ${ }^{4}$, except for Ireland where sectors F, I

\footnotetext{
${ }^{4}$ It thus covers the following sectors: (i) mining and quarrying (C), (ii) manufacturing (D), (iii) electricity, gas and water supply (E), (iv) wholesale and retail trade, repair of motor vehicles, motorcycles and personal and
} 
and $\mathrm{K}$ are not covered. According to the country considered, the number of observations ranges between 39,105 (Ireland) and 619,505 (Denmark). In order to distinguish the working hours wage gap from the gender wage gap, we have first restricted the sample to men only. Men's share of the total number of observations varies from $61 \%$ in the UK and Ireland to $77 \%$ in Spain. Moreover, observations were lost due to restriction of the sample to employees for whom information on supervision responsibilities was available but also due to data inconsistencies. Taking into account sample attrition, the final sample size used ranges between 20,206 men in Ireland ${ }^{5}$ and 201,601 in Denmark ${ }^{6}$. Note that the retained country samples remain representative of the entire male population.

Full-time and part-time employment can be defined in various ways. In the ESES, full-time employees are considered to be those who perform a full day's work for the entire week in the local unit. Part-time employees are considered to be those who, in accordance with a contract with their employer, do not perform a full day's work or do not complete a full week's work within the local unit. In other words, the survey defines part-time employment in terms of work status rather than on the basis of the number of working hours. For our purposes, this raises the question of whether the wage differential between part-time and full-time employees derives from their work status or from their working hours. The answer to this question goes beyond the subject of this article, in which we have decided to define part-time work by simultaneously accounting for work status and working hours. In other words, individuals were divided into two groups based on their work status as reported in the ESES, after which an additional selection removed from our sample those part-timers who work less than 15 hours per week and those full-timers who work less than 30 hours weekly. Workers whose weekly working hours are below 15 were omitted in order to eliminate the very casual workers who, by the definition of international organisations such as the ILO (1990), are considered to be inactive. By excluding this group of occasional workers, we avoid biasing

household goods (G), (v) hotels and restaurants (H), (vi) transport, storage and communication (I), (vii) financial intermediation (J), and (viii) real estate, renting and business activities (K).

${ }^{5}$ The definition of the Irish sample brought about substantial losses of observations when it was restricted to those individuals for whom information on any periods of absence from work was available (1,013 observations were lost).

${ }^{6}$ Besides sample attrition due to lacking information on educational attainments (32,777 observations), in Denmark, imposing the restriction on full-timers' and part-timers' working hours (to be considered full-timer one must work more than 30 hours a week and to be considered part-timer one works less than 30 hours but more than 15 hours a week) cuts the sample by 170,160 observations. This huge loss indicates the importance of very small part-time jobs in Denmark. Indeed, to quote Rasmussen et al. (2004: 645): "part-time employment has become a youth phenomenon, with around 60 per cent of part-timers now below 30 years of age and participating in some form of education". 
the genuine characteristics of workers with a stronger labour market attachment (working more than 15 hours a week).

The particular wage measure used in this study is gross hourly wage including overtime payments, premiums for shift work, night work and/or weekend work, but excluding bonuses (i.e. irregular payments which do not occur during each pay period, such as a holiday allowance, a "thirteenth month", profit sharing, etc.).

\section{Descriptive statistics}

Table 1 presents descriptive statistics with respect to the major variables of the present study. The proportion of part-timers among male employees varies substantially across the six countries analysed. It is as low as $0.7 \%$ in Italy, $1.0 \%$ in Spain, $1.2 \%$ in Belgium, $2.4 \%$ in Ireland and $2.5 \%$ in the United Kingdom and as high as $6.1 \%$ in Denmark. These figures respect the ranking of male part-time employment rates provided by international organisations such as the OECD or Eurostat that generally show male part-time work to be most frequent in the Nordic countries, the Netherlands and the UK (Eurostat, 2005; OECD, 2005).

As far as the educational distribution of workers according to work status is concerned, the general trend is that part-time working men are more present than their full-time colleagues among workers with at most a degree of lower secondary education, equally present in the middle group of workers with a degree of upper secondary (be it of general, technical, professional or artistic nature) and far less present among workers having a degree in higher education, be it of the university or non-university type, or having done a post-graduate course. However, the two Southern European countries form noticeable exceptions to this overall rule. In Italy, there appear to be only very small differences in the educational distribution of male part- and full-timers and in Spain, part-timers generally have higher educational attainments than full-timers.

In four out of the six countries studied (Belgium, Denmark, Spain and Italy), the pattern of general potential experience and tenure follows the expected trend among part-time and fulltime working men, i.e. part-timers, given their shorter educational experience, have more years of general labour market experience than their full-time colleagues but instead have fewer years of tenure (experience with the same employer) given their lower degree of job stability and the fact that they tend to be much more mobile on the labour market than fulltimers. 


\begin{tabular}{|c|c|c|c|c|c|c|c|c|c|c|c|c|}
\hline \multicolumn{13}{|l|}{ Variables } \\
\hline & \multicolumn{2}{|c|}{$\mathrm{BE}$} & \multicolumn{2}{|c|}{ DK } & \multicolumn{2}{|c|}{ IT } & \multicolumn{2}{|c|}{ ES } & \multicolumn{2}{|c|}{$\mathrm{IE}$} & \multicolumn{2}{|c|}{ UK } \\
\hline & Part-time & Full-time & Part-time & Full-time & Part-time & Full-time & Part-time & Full-time & Part-time & Full-time & Part-time & Full-time \\
\hline Gross hourly wage (in EURO) & 11.05 & 13.75 & 14.42 & 18.47 & 6.34 & 8.14 & 6.62 & 7.65 & 4.46 & 11.10 & 7.01 & 11.73 \\
\hline (full-time wage - part-time wage) / part-time wage & \multicolumn{2}{|c|}{$24 \%$} & \multicolumn{2}{|c|}{$28 \%$} & \multicolumn{2}{|c|}{$28 \%$} & \multicolumn{2}{|c|}{$16 \%$} & \multicolumn{2}{|c|}{$149 \%$} & \multicolumn{2}{|c|}{$67 \%$} \\
\hline General potential experience (years) & 14.76 & 9.69 & 13.75 & 13.33 & 14.77 & 12.37 & 13.15 & 13.51 & 5.63 & 9.14 & 20.18 & 15.71 \\
\hline Tenure (years) & 5.81 & 11.18 & 3.93 & 7.61 & 4.16 & 10.75 & 3.71 & 11.33 & 2.43 & 10.80 & 3.09 & 5.88 \\
\hline \multicolumn{13}{|l|}{ Education } \\
\hline no degree, primary or lower secondary & 45.52 & 35.97 & 44.89 & 26.07 & 61.56 & 62.75 & 54.71 & 63.52 & 32.83 & 32.65 & 60.31 & 42.86 \\
\hline general, technical, artistic or professional upper secondary & 38.77 & 39.99 & 50.30 & 53.99 & 36.73 & 32.28 & 21.24 & 16.63 & 62.22 & 45.90 & 29.05 & 36.51 \\
\hline higher non-university, university and post-graduate & 15.71 & 24.04 & 4.80 & 19.95 & 1.71 & 4.97 & 24.05 & 19.85 & 4.95 & 21.45 & 10.64 & 20.63 \\
\hline \multicolumn{13}{|l|}{ Occupation } \\
\hline legislators, senior officials and managers & 1.47 & 4.21 & 0.52 & 4.56 & 0.36 & 0.54 & 2.60 & 2.59 & 0.00 & 1.60 & 3.16 & 8.58 \\
\hline professionals & 2.48 & 3.62 & 0.61 & 5.38 & 0.85 & 2.24 & 5.47 & 2.95 & 0.08 & 4.03 & 0.96 & 4.95 \\
\hline technicians and associate professionals & 5.73 & 9.49 & 1.07 & 10.25 & 9.51 & 6.78 & 4.58 & 6.18 & 0.47 & 5.66 & 1.83 & 4.69 \\
\hline clerks & 10.92 & 8.59 & 0.67 & 2.61 & 6.58 & 8.54 & 10.29 & 5.55 & 0.74 & 4.48 & 12.24 & 6.43 \\
\hline service workers and shop and market sales workers & 33.74 & 29.13 & 7.35 & 26.90 & 40.51 & 22.38 & 36.07 & 22.72 & 70.22 & 24.01 & 47.96 & 28.33 \\
\hline craft and related trades workers & 6.76 & 11.18 & 22.39 & 11.79 & 8.12 & 15.36 & 5.09 & 12.70 & 4.20 & 10.17 & 2.83 & 10.75 \\
\hline plant and machine operators & 6.01 & 7.24 & 13.54 & 9.61 & 6.46 & 11.69 & 4.83 & 12.13 & 4.08 & 16.03 & 5.70 & 9.58 \\
\hline sales and services elementary occupations & 32.89 & 26.54 & 53.85 & 28.91 & 27.60 & 32.47 & 31.08 & 35.18 & 20.21 & 34.03 & 25.32 & 26.68 \\
\hline White-collar workers ${ }^{\star \star}$ & 0.53 & 0.55 & 0.11 & 0.49 & 0.53 & 0.41 & 0.59 & 0.41 & 0.68 & 0.40 & 0.64 & 0.53 \\
\hline \multicolumn{13}{|l|}{ Sector of activity } \\
\hline manufacture & 21.20 & 48.93 & 43.90 & 41.24 & 20.70 & 50.74 & 19.98 & 40.85 & 16.53 & 68.28 & 8.16 & 38.08 \\
\hline electricity, gas, steam and hot water supply, recycling & 0.72 & 2.42 & 0.28 & 1.20 & 1.18 & 2.48 & 0.08 & 1.77 & 0.26 & 5.97 & 0.18 & 1.50 \\
\hline construction & 2.96 & 6.99 & 29.27 & 10.77 & 3.33 & 6.47 & 7.80 & 15.30 & & & 1.04 & 7.91 \\
\hline wholesale and retail trade, repair of motor vehicles & 19.54 & 13.02 & 10.85 & 20.39 & 11.64 & 6.48 & 24.23 & 16.15 & 56.42 & 12.59 & 30.70 & 17.51 \\
\hline hotels and restaurants & 10.88 & 0.73 & 1.99 & 0.68 & 5.29 & 2.36 & 14.47 & 4.16 & 26.04 & 4.52 & 25.20 & 2.99 \\
\hline transport and travel & 10.95 & 5.39 & 6.55 & 6.22 & 11.21 & 14.39 & 8.32 & 6.11 & & & 4.28 & 7.96 \\
\hline post and telecommunications & 2.76 & 3.81 & 0.03 & 0.21 & 12.01 & 4.88 & 6.06 & 2.56 & & & 6.61 & 4.57 \\
\hline financial intermediation, insurance and pension funding & 5.83 & 9.67 & 0.94 & 6.97 & 1.78 & 5.41 & 4.58 & 7.49 & 0.75 & 8.63 & 2.35 & 6.24 \\
\hline real estate and renting & 0.59 & 0.65 & 1.38 & 2.13 & 0.00 & 0.07 & 1.66 & 0.78 & & & 1.81 & 2.05 \\
\hline computer and related activities & 1.63 & 1.48 & 0.18 & 2.59 & 0.38 & 1.70 & 0.24 & 0.45 & & & 0.26 & 1.52 \\
\hline other business activities & 22.94 & 6.89 & 4.62 & 7.60 & 32.48 & 5.03 & 12.57 & 4.37 & & & 19.42 & 9.66 \\
\hline Proportion of part-time/full-time workers & 0.01 & 0.99 & 0.06 & 0.94 & 0.01 & 0.99 & 0.01 & 0.99 & 0.02 & 0.98 & 0.03 & 0.98 \\
\hline Number of observations & 711 & 56568 & 12257 & 189344 & 506 & 66983 & 1317 & 125161 & 489 & 19717 & 1175 & 46750 \\
\hline
\end{tabular}
Number of observations

Notes: * Descriptive statistics refer to the weighted samples. For a more detailed description of the main variables, cfr. Appendix Table AI. ** White-collar occupations include the following categories of the 2-digit professionals, (31) physical and engineering science associate professionals, (32) life science and health associate professionals, (34) other associate professionals, (41) office clerks, (42) customer service clerks, (51) personal and protective services workers, and (52) models, salespersons and demonstrators. Blue-collar occupations include the following categories of the 2-digit International Standard Classification of Occupations (ISCO): (71) Extraction and building trades workers, (72) Metal, machinery and related trades workers, (73) Precision, handicraft, craft printing and related trades workers, (74) Other craft and related trades workers, (81) Stationary plant and related operators, (82) Machine operators and assemblers, (83) Drivers and mobile plant operators, (91) Sales and services elementary occupations, and (93) Labourers in mining, construction, manufacturing and transport. 
Note that the variable used measures potential experience and as such is likely to overestimate actual experience as it may mask spells of unemployment and inactivity throughout a worker's career. Therefore one should be cautious when comparing the return to this variable across countries given that it may be biased if part-time working men are more likely to interrupt their careers or for longer periods in some countries than in others, for example in response to policy initiatives to encourage fathers' involvement in childcare and other domestic responsibilities.

In Ireland, and to a lesser degree also in Spain, however, part-timers not only have very few years of tenure but they are also outnumbered by full-timers in terms of the number of years of general labour market experience. This is clearly related to the age structure of the male part-time work force which tends to be younger in these countries (Delsen, 1998; Ruivo et al., 1998). However, generally, part-time men have roughly 13-14 years of labour market experience (compared to 9-13 years among full-timers). Two countries deviate from this general finding, the UK where the number of years of experience is much higher (20 years compared to 16 years for full-timers) and Ireland where it is much smaller (6 years compared to 9 years for full-timers). This can at least partly be attributed to educational differences according to work status (part-time versus full-time) and again to a different age structure in the British and Irish samples. Part-timers appear to have between 4 and 6 years of tenure on average (compared to 8-11 years among full-timers), again with lower figures for Ireland and the UK.

The statistics on the proportion of male part- and full-timers being in white-collar occupations are particularly interesting. The share of part-time working men in white-collar occupations exceeds that of full-timers in Spain, Italy, Ireland and the UK by between 10 and 30\% whereas in Belgium, no difference worth mentioning exists according to work status and in Denmark, only $11 \%$ of male part-timers are white-collars compared to $49 \%$ of male fulltimers. A better understanding of these findings is obtained by looking at the distribution of part-time and full-time working men over the primary groups of occupations (corresponding to the one-digit ISCO-1988 classification). Indeed, in the former four countries, a far greater share of male part-timers are service workers, shop and market sales workers (ISCO5) but also clerks (ISCO4), except in Ireland and Italy. In Belgium, although this fact is less pronounced, it remains true that part-time workers are less present in high-responsibility occupations but more so in less demanding jobs as compared to full-time working men. Finally, the reverse trend that was observed for Denmark is due to the much larger proportions of part-time men compared to their full-time colleagues in the three main bluecollar occupational groups (craft and related trades workers (ISCO7), plant and machine operators (ISCO8) and sales and services elementary occupations (ISCO9)). 
Male part-timers are practically absent in real estate, electricity, gas, steam and hot water supply and recycling and in the computer business: less than $2 \%$ of all male part-timers are active in these industry branches in all countries. Less than $6 \%$ of male part-timers are in financial intermediation, insurance and pension funding and less than $7 \%$ in post and telecommunications (except for Italy where the share amounts to $12 \%$ of the male part-time workforce). Besides Denmark (29\%) and to a lesser degree Spain (8\%), they are also very poorly represented in the construction business. In contrast, the most important shares of male part-timers are to be found in wholesale and retail trade (56\% in Ireland, 31\% in the UK, 24\% in Spain, 20\% in Belgium and just above 10\% in Italy and Denmark) and in manufacture (44\% in Denmark, 21\% in Belgium and Italy, 20\% in Spain and 17\% in Ireland) although not in the UK (8\%). Considerable proportions of male part-timers are in other businesses except in Denmark (5\%). Hotels and restaurants appear to be particularly attractive to men working part-time in Ireland and the UK where their shares are far above the average, $26 \%$ and $25 \%$ respectively, compared to Denmark where only a mere $2 \%$ of the male part-time work force is occupied in this branch. Finally, between $4 \%$ and $11 \%$ are in transport and travel according to the country considered. In sum, our findings point out that male part-timers are heavily concentrated in industries such as manufacturing and as such in industries with a great sensitivity to business cycle variations ${ }^{7}$.

Full-time working men earn a wage that is on average 16\% higher than that of their part-timetime colleagues in Spain and as much as $149 \%$ higher in Ireland. In Belgium, Denmark and Italy, the part-time wage penalty is closer to the Spanish floor at $24-28 \%$ while in the UK it is much higher although it stays well below the Irish ceiling, at 67\%. The part-time wage penalty thus appears to be particularly severe for Irish men. The male part-time workforce in Ireland has some very distinctive traits. Male part-timers are much younger on average than in the other countries (Delsen, 1998), a characteristic which is signalled by the fact that they have markedly fewer years of general labour market experience, only about 6 years compared to between 13 and 20 years in the other countries. Nearly the entire male part-time workforce are sales and service workers very present in the wholesale and retail trade branch of activity. In Ireland only health and education related sectors are marked by relatively long working hours for part-timers whereas on general these are rather short. Given the highly feminised nature of these sectors, it seems reasonable to conclude that male part-timers overwhelmingly have very short working hours, a fact which renders their overall labour market situation very vulnerable and puts strong downward pressure on their wages. The fact that the smallest parttime wage penalty is observed among Spanish men should not come as a surprise since we know that the labour market in general and part-time work in particular are very rigidly

\footnotetext{
${ }^{7}$ Note that this is in contrast with what is commonly known about female part-time work, concentrated in services, especially in the public sector as a result of historical labour market and social developments.
} 
regulated in Spain. Part-time work has not increased flexibility nor did it bring about cost advantages for employers in the mid 90s. On the contrary, part-time work was subject to the same rules (pro rata) as full-time work and part-timers enjoyed the same degree of job security as full-timers. A wave of deregulation was launched in 1994 but its effects are not yet captured by the data used in this paper (Gómez et al., 2002; Cebrián et al., 2001).

At first view, the descriptive statistics suggest that the wage difference between full-time and part-time employed men is due to the accumulation of disadvantaging individual as well as job characteristics. However, in order to fully understand the wage gap we need to rely on a multivariate analysis as the one described in section 2.

\section{Wage equations and decomposition results}

In this section we examine the results of our wage equation estimations and decompositions, as specified in section 2. The first set of estimations includes only human capital indicators as explanatory variables (six categories indicating the level of education and ranging from primary to post-graduate education with a primary school degree being the reference, prior potential experience, its square and its cube and seniority, its square and its cube), and aims at estimating the part-time/full-time wage gap "market-wide"8. As shown in Table 2, in monetary terms, the wage gap varies between 1.01 EUR per hour in Spain and 6.64 EUR in Ireland.

Table 2: Estimated wage gaps and Oaxaca-Blinder decomposition

\begin{tabular}{|c|c|c|c|c|c|c|}
\hline & $\mathrm{BE}$ & DK & IT & ES & IE & UK \\
\hline \multicolumn{7}{|l|}{ human capital model } \\
\hline \multicolumn{7}{|l|}{ overall wage gap } \\
\hline (wage ft - wage pt) in EURO & 2.58 & 4.05 & 1.98 & 1.01 & 6.64 & 4.72 \\
\hline (wage $\mathrm{ft}$ - wage $\mathrm{pt}$ ) / wage $\mathrm{pt}$ & 0.24 & 0.28 & 0.28 & 0.16 & 1.49 & 0.67 \\
\hline $\log ($ wage ft) - log (wage pt) & 0.27 & 0.23 & 0.24 & 0.29 & 0.87 & 0.55 \\
\hline non-explained part (in \% of total gap) & $0.14^{\star \star \star}(51.8 \%)$ & $0.07^{\star \star \star}(28.6 \%)$ & $0.09^{\star \star}(37.7 \%)$ & $0.12^{\star \star \star}(42.2 \%)$ & $0.41^{\star \star \star}(47.2 \%)$ & $0.38^{\star \star \star}(68.6 \%)$ \\
\hline explained part (in \% of total) & $0.13^{\star \star \star}(48.2 \%)$ & $0.16^{\star \star \star}(71.4 \%)$ & $0.15^{\star \star \star}(62.3 \%)$ & $0.17^{\star \star \star}(57.8 \%)$ & $0.46^{\star \star \star}(52.8 \%)$ & $0.17^{\star \star \star}(31.4 \%)$ \\
\hline \multicolumn{7}{|l|}{ model with whole set of controls } \\
\hline \multicolumn{7}{|l|}{ overall wage gap } \\
\hline (wage $\mathrm{ft}$ - wage pt) in EURO & 2.58 & 4.05 & 1.98 & 1.01 & 6.64 & 4.72 \\
\hline (wage $\mathrm{ft}$ - wage $\mathrm{pt}$ ) / wage pt & 0.24 & 0.28 & 0.28 & 0.16 & 1.49 & 0.67 \\
\hline non-explained part (in \% of total gap) & $0.07^{\star \star \star}(28.1 \%)$ & $-0.01^{\star \star \star}(-5.1 \%)$ & $0.13^{\star \star \star}(51 \%)$ & $0.06^{\star \star \star}(19.8 \%)$ & $0.29^{\star \star \star}(33.3 \%)$ & $0.15^{\star \star \star}(27.3 \%)$ \\
\hline explained part (in \% of total) & $0.19^{\star \star \star}(71.9 \%)$ & $0.24^{\star \star \star}(105.1 \%)$ & $0.12^{\star \star \star}(49.0 \%)$ & $0.23^{\star \star \star}(80.2 \%)$ & $0.57^{\star \star \star}(66.7 \%)$ & $0.40^{\star \star \star}(72.7 \%)$ \\
\hline
\end{tabular}

Notes: $* * * / * * *$ : coefficient significant at the 1,5 , and 10 per cent level, respectively. The level of significance of the different components of the part-time/full-time wage gap was computed following the example set by Oaxaca and Ransom (1998).

\footnotetext{
${ }^{8}$ Results from the wage regressions are reported in Appendix Table A.II.
} 
Human capital differences explain between $31.4 \%$ of the observed wage gap in the UK and 71.4\% in Denmark. In monetary terms, controlling for human capital differences reduces the hourly part-time wage penalty from 4.72 EUR to 3.24 EUR in the UK and from 4.05 EUR to 1.16 EUR in Denmark. These remainders of the original wage gaps are unexplained and may be due to direct discriminatory pay practices, indirect forms of discrimination (e.g. professional and occupational segregation) or unobserved productivity-related characteristics. Controlling for differences in human capital between male part-timers and full-timers slightly modifies the country ranking in terms of the size of the wage gap. At the bottom end, nothing changes, the wage gap remains smallest in Spain and Italy still comes in second. However, the addition of human capital controls has made the Danish gap become smaller than the Belgian one. Also, Ireland and the UK change places at the top of the ranking: after controlling for human capital, the gap is largest in the UK whereas Ireland sets forth the second largest gap. Note that both the explained and the unexplained component of the Oaxaca (1973) and Blinder (1973) decomposition are statistically significant at the $5 \%$ level.

The second set of estimations includes the widest possible set of control variables (42 industry and 20 occupational covariates, dummies indicating paid overtime, bonuses for shift work, night work or weekend work and supervision responsibilities with respect to co-workers, region, level of collective bargaining, type of employment contract, type of economic and financial control of the establishment, and its size $)^{9}$. Computing this second set of estimations has been done for two main reasons. As the descriptive data showed, part-time employment often has very different features than full-time employment. Therefore, we believe that linking wage determination to types of job may reveal more correct explanations for the observations above. We have therefore applied an extended human capital approach incorporating into the wage equation variables that account for the labour market situation of employees. The idea is to adjust wages for the differentials generated by the varying nature of employment. One could argue that industrial and occupational variables are endogenous to discrimination as they are likely to be a reflection of labour market discrimination in itself and that these variables are unsuitable for this type of analysis. However, controlling for industry and occupational groups is of importance if we are to try to understand the wage-gap between part-timers and full-timers. Thus in the following we are not investigating a "market wide" wage gap, as above, but rather a "within industry/occupational group and establishment" wage gap. One has to bear in mind the influence of adding variables to the wage regression as well as its impact on the wage decomposition. It is well known (Cain, 1986) that the choice of variables has an arbitrary influence on the decomposition between a price effect and a characteristics effect, the price effect tending to decrease with an increase in the number of

\footnotetext{
${ }^{9}$ Results from the wage regressions are reported in Appendix Table A.III.
} 
variables. However, taking these two comments into consideration we still think it is of use for the present analysis to include labour market variables.

As shown in Table 2, when the whole set of explanatory variables is included in the wage regressions, a much larger part of the gap is explained by differences in observed characteristics (except in Italy). The share of the explained part of the part-time/full-time wage gap is respectively 49\% in Italy, 67\% in Ireland, 72\% in Belgium, $73 \%$ in the UK, 80\% in Spain and 105\% in Denmark. Including the whole set of control variables again changes the country ranking according to the size of the wage gap between men working part-time and full-time. The gap in Denmark completely disappears. Spain holds on to its respective position at the bottom of the ranking and the UK and Ireland to their leading places but in between Belgium and Italy switch ranks. Indeed, controlling for the whole range of personal and establishment characteristics considerably reduces the Belgian gap so that it falls well behind the Italian one. Testing for statistical significance shows that both the unexplained wage gap and the explained are highly significant in all countries, at the $1 \%$ level. The fact that the explained part of the gap decreases in Italy after adding industrial, occupational and other control variables relative to workers' labour market situation is difficult to explain. It suggests that men working part-time are better endowed as regards these characteristics than their full-time working colleagues. A hint towards this finding was already given by our descriptive statistics. Indeed, approximately one third of male part-timers (compared to just $5 \%$ of full-timers) are in other business activities associated with favourable wage conditions $^{10}$. In Italy, although $53 \%$ of part-timers versus $41 \%$ of full-timers are in whitecollar occupations, which are generally less physically demanding and more highly paid, a closer look shows that they are particularly overrepresented amongst service workers and shop and market sales workers, probably the least well-off in terms of wage in the whitecollar group. As a result, the sector-level argument seems decisive in the Italian case. The Danish case is somewhat peculiar in that the wage-gap is entirely explained by differences in characteristics of individuals and jobs. In other words, the price effect completely disappears once industries, occupations and establishment characteristics are included in the regression. This could indicate that the selection of men with a higher earning capacity into full-time employment is more a selection of men into specific types of jobs that are not available to part-time men and that this is the reason for the negative price-effect. A hint towards such strong occupational segregation was already given by our descriptive statistics that show that

\footnotetext{
${ }^{10}$ Other business activities include : (i) legal, accounting, book-keeping and auditing activities ; tax consultancy ; market research and public opinion polling; business and management consultancy; holding, (ii) architectural and engineering activities and related technical consultancy, (iii) technical testing and analysis, (iv) advertising, (v) labour recruitment and provision of personnel, (vi) investigation and security activities, (vii) industrial cleaning, and (viii) miscellaneous business activities.
} 
only $11 \%$ of part-timers hold white-collar occupations compared to $49 \%$ of full-timers. Nevertheless, this contrasts with Fagan and Rubery (1996) who, within the European Union, found Denmark to be the country with the highest level of occupational gender segregation but restricting the analysis to full-timers barely changed the index of segregation. As a result, segregation of part-timers in lower-paid sectors of activity also seems to play an important role in Denmark although this is less evident from our descriptive statistics.

\section{Conclusion}

Economic theory advances a number of reasons for the existence of a wage gap between parttime and full-time workers. Empirical work has concentrated on the wage effects of part-time work for women. For men, much less empirical evidence exists. Moreover, we are not aware of a single study that presents cross-country evidence regarding the issue.

The main reason for this lack of empirical work on the part-time wage penalty for men is that in most countries they only make up a very small proportion of the part-time work force and thus most data bases contain too little observations on male part-timers for statistical studies to yield reliable results. Given the narrow literature on the subject of male part-time work, we believe this paper to make a valuable contribution.

The analysis is based on the European Structure of Earnings Survey, an employer-employee matched data base that is well suited for this type of research. It provides harmonised information - provided by the establishments' management - on large numbers of both establishments (e.g. sector of activity, size of the firm, and level of wage bargaining) and employees (e.g. age, education, gross hourly wage, sex, and occupation) of the private sector in six European countries: Belgium, Denmark, Ireland, the UK, Italy and Spain.

The main question this paper attempts to respond to, is how part-time work affects men's wages in these six European member states. We find that the raw gap in hourly gross pay amounts to $16 \%$ of a male part-timer's wage in Spain (or to 1 EUR), to $24 \%$ in Belgium (roughly 2.5 EUR), 28\% in Denmark and Italy (roughly 4 and 2 EUR respectively), to 67\% in the UK (4.7 EUR) and to 149\% in Ireland (6.6 EUR). Human capital differences explain between $31.4 \%$ of the observed wage gap in the UK (or 1.5 EUR of the total gap of 4.7 EUR) and $71.4 \%$ in Denmark (or 2.9 EUR of the total 4 EUR gap). The inclusion of human capital makes the Danish gap become smaller than the Belgian one. Also, Ireland and the UK change places at the top of the ranking: after controlling for human capital, the gap is largest in the UK whereas Ireland sets forth the second largest gap. 
In sum, from these first regressions, it becomes clear that in most countries part-time working men have lower educational attainments and other human capital assets than their full-time colleagues. As a result, policy initiatives to promote life-long learning and training are proven of great importance to help part-timers catch up.

When the whole set of explanatory variables are included in the wage regressions, a much larger part of the gap is explained by differences in observed characteristics (except in Italy where the historical development of part-time work has prevented its occupational and industrial stigmatisation more markedly than in the other countries). The share of the explained part of the part-time/full-time wage gap is respectively $49 \%$ in Italy (or roughly 1 EUR), $67 \%$ in Ireland (or 4.4 EUR), $72 \%$ in Belgium (or 1.9 EUR), $73 \%$ in the UK (or 3.4 EUR), 80\% in Spain (0.8 EUR) and 105\% in Denmark (or 4.3 EUR). Including the whole set of control variables once again changes the country ranking. The gap in Denmark disappears. Spain holds on to its respective position at the bottom of the ranking and the UK and Ireland to their leading places but in between Belgium and Italy switch ranks. Indeed, controlling for the whole range of personal and establishment characteristics considerably reduces the Belgian gap so that it falls well behind the Italian one.

A problem of occupational and professional segregation ${ }^{11}$ thus clearly persists on the Belgian, British, Irish, Spanish and Danish labour markets. Segregation is by far largest in the UK where it explains $41.3 \%$ or 1.95 EUR of the total part-time/full-time wage gap. Denmark comes in second with a share of $33.7 \%$ or 1.36 EUR of the gap explained by the fact that male part-timers are over-represented in less well-paid occupations and sectors of activity. Belgium and Spain have comparable levels of segregation although in monetary terms it explains 0.61 EUR in Belgium compared to just 0.23 EUR in Spain. Ireland holds an intermediate position with 0.92 EUR of its total wage gap being explained by occupational and sectoral segregation (or the fact that part-timers are to be found in smaller establishments). However, in relative terms, Ireland is characterised by the smallest share of its wage gap due to segregation (13.9\%). On the contrary, in Italy part-timers seem to hold such occupations and be active in such establishments and sectors of economic activity that offer more favourable wage conditions than full-timers. This result is very difficult to interpret although some hints were provided by our descriptive statistics. The persistence of labour market segregation calls for specific policy answers.

To conclude, let us notice that even after controlling for occupational and sectoral differences, a sometimes important gap remains. This result may be explained by the fact that we are not

\footnotetext{
${ }^{11}$ To be very precise we should add segregation across different sizes of establishments since this is a control variable we also add at this stage of the wage estimations.
} 
able to correct for potential workers' self-selection into part-time and full-time employment. However, it may also highlight the existence of direct forms of discrimination with respect to part-time working men, a finding that once again would call for urgent policy attention. 


\section{References}

Bardasi, E. and Gornick, J. C. (2000), “Women and part-time employment: Workers' "choices" and wage penalties in five industrialized countries", Institute for Social and Economic Research, ISER Discussion Paper, No. 2000-11, 54 p.

Bardasi, E. and Gornick, J. C. (2002), "Explaining cross-national variation in part-time/fulltime wage differentials among women”, Paper prepared for presentation at the workshop on "Comparative political economy of inequality”, Cornell University, Ithaca, New York, April 5-7, 62 p.

Barzel, Y. (1973), “The determination of daily hours and wages”, Quarterly Journal of Economics, Vol. 87 No. 2, pp. 220-38.

Blinder, A. (1973), "Wage discrimination: Reduced form and structural estimates”, Journal of Human Resources, Vol. 7 No. 4, pp. 436-55.

Booth, A. and Wood, M. (2004), "Back-to-front down-under? Part-time/full-time wage differentials in Australia”, IZA Discussion paper, N²268, August, 30p.

Cain, G. (1986) "The economic analysis of labor market discrimination: a survey", in Ashenfelter, O. and Laynard, R. (Eds), Handbook of Labor Economics, Vol. 1 No. 13, Elsevier Science Publishers BV, pp. 693-785.

Cebrián, I., Moreno, G., Samek, M., Semenza, R. and Toharia, L. (2001), “Atypical work in Italy and Spain: The quest for flexibility at the margin in two supposedly rigid labor markets", Paper presented at the conference on "Nonstandard work arrangements in Japan, Europe, and the United States”, W.E. Upjohn Institute for Employment Research, Kalamazoo, Michigan, August 25-26, 45p.

Delsen, L. (1998), “When do men work part-time?”, in O’Reilly, J. and Fagan, C. (Eds), Parttime prospects: An international comparison of part-time work in Europe, North America and the Pacific Rim, Routledge, London and New York, pp. 57-76.

Ermisch, J.F. and Wright, R.E. (1991), "Wage offers and full-time and part-time employment by British women”, Journal of Human Resources, Vol. 25 No.1, pp. 111-33.

European Foundation for the Improvement of Living and Working Conditions (2005), "Parttime work in Europe”, Report, 20p.

(http://www.eurofound.eu.int/ewco/reports/TN0403TR01/TN0403TR01.pdf)

Eurostat (2005), The European Labour Force Survey 2005, European Commission. (http://epp.eurostat.ec.europa.eu/)

Fagan, C. and Rubery, J. (1996), "The salience of the part-time divide in the European Union”, European Sociological Review, Vol. 12 No. 3, pp. 227-50.

Ferber, M. A. and Waldfogel, J. (1998), “The long-term consequences of non-traditional employment”, Monthly Labor Review, Vol. 121 No. 5, pp. 3-12.

Gómez, S., Pons, C. and Martí, C. (2002), "Part-time work: Its evolution and results", University of Navarra, IESE Business School, Research paper, No. D/476, October, 15 p. 
Hagemann, H. (1994), “Teilen und Gewinnen - Das Potential der flexiblen Arbeitszeitverkürzung”, McKinsey \& Co. Inc.

Hamermesh, D.S. and Rees, A. (1993), The economics of work and pay, New York, Harper Collins College Publishers, Fifth Edition.

Hardoy, I. and Schøne, P. (2006), "The part-time wage gap in Norway: How large is it really?”, British Journal of Industrial Relations, Vol. 44 No. 2, pp. 263-82.

Heckman, J. J. (1979), “Sample selection bias as a specification error”, Econometrica, Vol. 47 No. 1, pp. 153-61.

Hirsch, B. (2005), "Why do part-time workers earn less? The role of worker and job skills", Industrial and Labor Relations Review, Vol. 58 No. 4, pp. 525-51.

$\mathrm{Hu}, \mathrm{Y}$. and Tijdens, K. (2003), "Choices for part-time jobs and the impacts on the wage differentials. A comparative study for Great Britain and the Netherlands”, An Integrated Research Infrastructure in the Socio-Economic Sciences at CEPS/INSTEAD, IRISS Working Paper, No. 2003-05, 36p.

ILO (1990), Employment, unemployment and underemployment. An ILO manual on concepts and methods, Geneva.

Jepsen, M. (2001), “Some evidence on the price for working part-time”, PhD in Economics, Université Libre de Bruxelles.

Jepsen, M., O’Dorchai, S., Plasman, R. and Rycx, F. (2005), “The Wage Penalty Induced by Part-Time Work: The Case of Belgium”, Brussels Economic Review, Vol. 48, No. 1/2, pp. 73-94.

Koskela, E. and Schöb, R. (1999), "Does the composition of wage and payroll taxes matter under Nash bargaining?”, Economics Letters, Vol. 64 No. 3, pp. 343-49.

Koskela, E. and Vilmunen, J. (1996), “Tax progression is good for employment in popular models of trade union behaviour”, Labour Economics, Vol. 3 No. 1, pp. 65-80.

Lindbeck, A. and Snower, D.J. (2000), “Multitask learning and the reorganization of work: From tayloristic to holistic organization”, Journal of Labor Economics, Vol. 18 No. 3, pp. 353-76.

Main, B. and Reilly, B. (1992), “Women and the union wage gap”, Economic Journal, Vol. 102 No. 410, pp. 49-66.

Manning, A. and Petrongolo, B. (2005), “The part-time pay penalty”, CEP Discussion Paper, No. 679, 97p.

Manski, C. (1995), Identification problems in social sciences, Harvard University Press, Cambridge, M.A.

McGuire, J.B. and Liro, J.R. (1986), "Flexible work schedules, work attributes, and perceptions of productivity”, Public Personnel Management, Vol. 15 No. 1, pp. 65-73.

Mincer, J. (1974), Schooling, experience and earnings, Columbia University Press, New York, NY. 
Moffitt, R. (1984), “The estimation of a joint wage-hours labor supply model”, Journal of Labor Economics, Vol. 2 No. 4, pp. 550-66.

Montgomery, M. (1988), “On the determinants of employer demand for part-time workers”, Review of Economics and Statistics, Vol. 70 No. 1, pp. 112-16.

Oaxaca, R. (1973), "Male-female wage differentials in urban labor markets”, International Economic Review, Vol. 14 No. 3, pp. 693-709.

Oaxaca, R. and Ransom, M. (1994), "On discrimination and the decomposition of wage differentials”, Journal of Econometrics, Vol. 61 No. 1, pp. 5-21.

Oaxaca, R. and Ransom, M. (1998), "Calculation of approximate variance for the wage decomposition differentials”, Journal of Economic and Social Measurement, Vol. 24 No. 1, pp. 55-61.

OECD Statistics (2005) (http://stats.oecd.org/WBOS/Default.aspx).

Oi, W. (1962), “Labour as a quasi-fixed cost”, Journal of Political Economy, Vol. 70 No. 6, pp. 538-55.

Rasmussen, E., Lind, J. and Visser, J. (2004), "Divergence in Part-Time Work in New Zealand, the Netherlands and Denmark”, British Journal of Industrial Relations, Vol. 42 No. 4, pp. 637-58.

Riley, N.-M. (1997), “Determinants of union membership: a review”, Labour, Vol. 11 No. 2, pp. 265-301.

Rodgers, J. R. (2004), "Hourly wages of full-time and part-time employees in Australia”, Australian Journal of Labour Economics, Vol. 7 No. 2, pp. 231-54.

Rose, K. (1998), "Work/life flexibility: A key to maximizing productivity”, HR Advisory, Vol. 6 No. 1, pp. 10-7.

Ruivo M., do Pilar González, M. and Varejão, J. (1998), "Why is part-time work so low in Portugal and Spain?”, in O’Reilly, J. and Fagan, C. (Eds) Part-time prospects - An international comparison of part-time work in Europe, North America and the Pacific Rim, Routledge, London, pp. 199-213.

Russo, G. and Hassink, W. (2005), “The part-time wage penalty: A career perspective”, IZA Discussion Paper, No. 1468, 26p.

Shepard, E.E., Clifton, T.J. and Kruse, D. (1996), "Flexible work hours and productivity: Some evidence from the pharmaceutical industry”, Industrial Relations, Vol. 35 No. 1, pp. 123-39.

Skåtun, J.D. (1998), "Divide the hours and conquer the surplus: part-time workers and pay”, Economics Letters, Vol. 61 No. 2, pp. 235-42.

Stewart, M.B. (1983), "Relative earnings and individual union membership in the United Kingdom”, Economica, Vol. 50 No. 198, pp. 111-25.

Tummers, M.P. and Woittiez, I. (1991), “A simultaneous wage and labor supply model with hours restrictions”, Journal of Human Resources, Vol. 26 No. 3, pp. 393-423. 
US Department of Labor (2006), “Employment status of women and men in 2005”, Women’s Bureau, fact sheet. (http://www.dol.gov/wb/factsheets/Qf-ESWM05.htm)

Vella, F. (1993), "Nonwage benefits in a simultaneous model of wages and hours: Labour supply functions of young female”, Journal of Labor Economics, Vol. 11 No. 4, pp. 70423.

Vella, F. (1998), “Estimating models with sample selection bias: a survey”, Journal of Human Resources, Vol. 33 No. 1, pp. 127-72.

Vella, F. and Verbeek, M. (1998), "Whose wages do unions raise? A dynamic model of unionism and wage rate determination for young men”, Journal of Applied Econometrics, Vol. 13 No. 2, pp. 163-83.

White, H. (1980), “A heteroscedasticity-consistent covariance matrix estimator and a direct test for heteroscedasticity”, Econometrica, Vol. 48 No. 4, pp. 817-30. 


\section{Appendix}

\section{Table AI. Description and means of selected variables}

\begin{tabular}{|c|c|c|c|c|c|c|c|c|c|c|c|c|}
\hline \multicolumn{13}{|l|}{ Variables } \\
\hline & \multicolumn{2}{|c|}{$\mathrm{BE}$} & \multicolumn{2}{|c|}{ DK } & \multicolumn{2}{|c|}{ IT } & \multicolumn{2}{|c|}{ ES } & \multicolumn{2}{|c|}{$\mathrm{IE}$} & \multicolumn{2}{|c|}{ UK } \\
\hline & Part-time & Full-time & Part-time & Full-time & Part-time & Full-time & Part-time & Full-time & Part-time & Full-time & Part-time & Full-time \\
\hline $\begin{array}{l}\text { Gross hourly wage: (in EURO) includes paid overtime, premiums } \\
\text { for shift work, night work and/or weekend work but excludes } \\
\text { bonuses (i.e. irregular payments which do not occur during each } \\
\text { pay period, such as holiday allowances, a thriteenth month, profit } \\
\text { sharing, etc.) }\end{array}$ & 11.05 & 13.75 & 14.42 & 18.47 & 6.34 & 8.14 & 6.62 & 7.65 & 4.46 & 11.10 & 7.01 & 11.73 \\
\hline Wage gap : (full-time wage - part-time wage) / part-time wage & \multicolumn{2}{|c|}{$24 \%$} & \multicolumn{2}{|c|}{$28 \%$} & \multicolumn{2}{|c|}{$28 \%$} & \multicolumn{2}{|c|}{$16 \%$} & \multicolumn{2}{|c|}{$149 \%$} & \multicolumn{2}{|c|}{$67 \%$} \\
\hline $\begin{array}{l}\text { General potential experience: (years) experience (potentially) } \\
\text { accumulated on the labour market before the last job, computed as } \\
\text { follows: age - } 6 \text { - years of education - seniority }\end{array}$ & 14.76 & 9.69 & 13.75 & 13.33 & 14.77 & 12.37 & 13.15 & 13.51 & 5.63 & 9.14 & 20.18 & 15.71 \\
\hline Seniority in the firm: (years) & 5.81 & 11.18 & 3.93 & 7.61 & 4.16 & 10.75 & 3.71 & 11.33 & 2.43 & 10.80 & 3.09 & 5.88 \\
\hline \multicolumn{13}{|l|}{ Education } \\
\hline Primary or no degree & 21.72 & 13.16 & 11.25 & 9.02 & 16.90 & 15.66 & 16.66 & 34.34 & 3.95 & 6.99 & 32.31 & 22.80 \\
\hline Lower secondary & 23.80 & 22.81 & 33.42 & 16.72 & 44.66 & 47.09 & 38.05 & 29.18 & 28.88 & 25.66 & 27.41 & 20.00 \\
\hline Upper secondary (General/Technical/Artistic/Professional) & 38.77 & 39.99 & 50.48 & 54.31 & 36.73 & 32.28 & 21.24 & 16.63 & 62.22 & 45.90 & 29.53 & 36.45 \\
\hline Higher non-university short type, higher artistic training & 10.17 & 13.01 & 2.35 & 5.48 & 0.18 & 0.36 & 6.00 & 8.70 & 3.24 & 13.70 & 4.39 & 8.17 \\
\hline University and non-university higher education, long type & 5.29 & 10.41 & 1.44 & 9.04 & 1.53 & 4.57 & 16.94 & 11.09 & 1.11 & 6.52 & 6.11 & 10.66 \\
\hline Post-graduate & 0.25 & 0.62 & 1.06 & 5.43 & 0.00 & 0.04 & 1.11 & 0.06 & 0.60 & 1.23 & 0.25 & 1.92 \\
\hline \multicolumn{13}{|l|}{ Occupation } \\
\hline legislators, senior officials and managers & 1.47 & 4.21 & 0.52 & 4.56 & 0.36 & 0.54 & 2.60 & 2.59 & 0.00 & 1.60 & 3.16 & 8.58 \\
\hline professionals & 2.48 & 3.62 & 0.61 & 5.38 & 0.85 & 2.24 & 5.47 & 2.95 & 0.08 & 4.03 & 0.96 & 4.95 \\
\hline technicians and associate professionals & 5.73 & 9.49 & 1.07 & 10.25 & 9.51 & 6.78 & 4.58 & 6.18 & 0.47 & 5.66 & 1.83 & 4.69 \\
\hline clerks & 10.92 & 8.59 & 0.67 & 2.61 & 6.58 & 8.54 & 10.29 & 5.55 & 0.74 & 4.48 & 12.24 & 6.43 \\
\hline service workers and shop and market sales workers & 33.74 & 29.13 & 7.35 & 26.90 & 40.51 & 22.38 & 36.07 & 22.72 & 70.22 & 24.01 & 47.96 & 28.33 \\
\hline craft and related trades workers & 6.76 & 11.18 & 22.39 & 11.79 & 8.12 & 15.36 & 5.09 & 12.70 & 4.20 & 10.17 & 2.83 & 10.75 \\
\hline plant and machine operators & 6.01 & 7.24 & 13.54 & 9.61 & 6.46 & 11.69 & 4.83 & 12.13 & 4.08 & 16.03 & 5.70 & 9.58 \\
\hline sales and services elementary occupations & 32.89 & 26.54 & 53.85 & 28.91 & 27.60 & 32.47 & 31.08 & 35.18 & 20.21 & 34.03 & 25.32 & 26.68 \\
\hline \multicolumn{13}{|l|}{ White-collar workers: (yes) workers registered within ISCO codes } \\
\hline 12 to $52^{*}$ & 0.53 & 0.55 & 0.11 & 0.49 & 0.53 & 0.41 & 0.59 & 0.41 & 0.68 & 0.40 & 0.64 & 0.53 \\
\hline \multicolumn{13}{|l|}{ Sector of activity } \\
\hline manufacture & 21.20 & 48.93 & 43.90 & 41.24 & 20.70 & 50.74 & 19.98 & 40.85 & 16.53 & 68.28 & 8.16 & 38.08 \\
\hline electricity, gas, steam and hot water supply, recycling & 0.72 & 2.42 & 0.28 & 1.20 & 1.18 & 2.48 & 0.08 & 1.77 & 0.26 & 5.97 & 0.18 & 1.50 \\
\hline construction & 2.96 & 6.99 & 29.27 & 10.77 & 3.33 & 6.47 & 7.80 & 15.30 & & & 1.04 & 7.91 \\
\hline wholesale and retail trade, repair of motor vehicles & 19.54 & 13.02 & 10.85 & 20.39 & 11.64 & 6.48 & 24.23 & 16.15 & 56.42 & 12.59 & 30.70 & 17.51 \\
\hline
\end{tabular}


Table AI. Description and means of selected variables (continued)

\begin{tabular}{|c|c|c|c|c|c|c|c|c|c|c|c|c|}
\hline & \multicolumn{2}{|c|}{$\mathrm{BE}$} & \multicolumn{2}{|c|}{ DK } & \multicolumn{2}{|c|}{ IT } & \multicolumn{2}{|c|}{ ES } & \multicolumn{2}{|c|}{$\mathrm{IE}$} & \multicolumn{2}{|c|}{ UK } \\
\hline & Part-time & Full-time & Part-time & Full-time & Part-time & Full-time & Part-time & Full-time & Part-time & Full-time & Part-time & Full-time \\
\hline \multicolumn{13}{|l|}{ Sector of activity (continued) } \\
\hline hotels and restaurants & 10.88 & 0.73 & 1.99 & 0.68 & 5.29 & 2.36 & 14.47 & 4.16 & 26.04 & 4.52 & 25.20 & 2.99 \\
\hline transport and travel & 10.95 & 5.39 & 6.55 & 6.22 & 11.21 & 14.39 & 8.32 & 6.11 & & & 4.28 & 7.96 \\
\hline post and telecommunications & 2.76 & 3.81 & 0.03 & 0.21 & 12.01 & 4.88 & 6.06 & 2.56 & & & 6.61 & 4.57 \\
\hline financial intermediation, insurance and pension funding & 5.83 & 9.67 & 0.94 & 6.97 & 1.78 & 5.41 & 4.58 & 7.49 & 0.75 & 8.63 & 2.35 & 6.24 \\
\hline real estate and renting & 0.59 & 0.65 & 1.38 & 2.13 & 0.00 & 0.07 & 1.66 & 0.78 & & & 1.81 & 2.05 \\
\hline computer and related activities & 1.63 & 1.48 & 0.18 & 2.59 & 0.38 & 1.70 & 0.24 & 0.45 & & & 0.26 & 1.52 \\
\hline other business activities & 22.94 & 6.89 & 4.62 & 7.60 & 32.48 & 5.03 & 12.57 & 4.37 & & & 19.42 & 9.66 \\
\hline Paid overtime: (yes) & 5.83 & 10.43 & 31.57 & 26.64 & 9.81 & 43.83 & 4.48 & 10.86 & 7.8 & 43.96 & 27.63 & 40.78 \\
\hline Bonuses for shift work, night work and/or weekend work: (yes) & 15.66 & 21.47 & 45.32 & 28.53 & 14.08 & 23.90 & 16.85 & 16.01 & 1.82 & 24.50 & 15.23 & 16.39 \\
\hline \multicolumn{13}{|l|}{ Type of contract } \\
\hline Unlimited-term employment contract & 90.49 & 97.64 & 89.24 & 94.38 & 81.62 & 95.19 & 40.40 & 75.19 & 93.01 & 94.21 & 82.57 & 91.62 \\
\hline Limited-term employment contract & 7.81 & 1.89 & 3.73 & 0.94 & 15.78 & 1.89 & 58.80 & 24.27 & 2.88 & 3.87 & 13.83 & 6.44 \\
\hline Apprentice/trainee contract or other type & 1.70 & 0.47 & 7.03 & 4.68 & 2.60 & 2.92 & 0.80 & 0.54 & 4.11 & 1.92 & 3.60 & 1.94 \\
\hline Supervises the work of co-workers: (yes) & 10.72 & 19.46 & 1.56 & 16.82 & 7.29 & 16.36 & & & 1.48 & 11.94 & 5.25 & 20.56 \\
\hline Size of the establishment: number of workers & 85.06 & 175.52 & 138.05 & 133.47 & 106.62 & 106.34 & 48.68 & 99.13 & 628.91 & 286.61 & 1481.60 & 705.76 \\
\hline \multicolumn{13}{|l|}{ Economic and financial control of the establishment } \\
\hline Fully state-owned & 2.88 & 3.95 & na & na & na & na & 5.29 & 4.90 & 0.00 & 8.70 & 6.52 & 5.89 \\
\hline Public firm (>50 per cent state-owned) & 2.97 & 4.11 & 0.90 & 1.45 & na & na & 0.81 & 1.92 & 0.00 & 0.04 & na & na \\
\hline Private firm (>50 per cent privately owned) & 79.33 & 84.31 & 99.10 & 98.55 & na & na & 93.23 & 91.81 & 100.00 & 91.26 & 93.48 & 94.11 \\
\hline Other & 14.82 & 7.63 & na & na & na & na & 0.67 & 1.37 & na & na & na & na \\
\hline Proportion of part-time/full-time workers & 0.01 & 0.99 & 0.06 & 0.94 & 0.01 & 0.99 & 0.01 & 0.99 & 0.02 & 0.98 & 0.03 & 0.98 \\
\hline Number of observations & 711 & 56568 & 12257 & 189344 & 506 & 66983 & 1317 & 125161 & 489 & 19717 & 1175 & 46750 \\
\hline
\end{tabular}

\section{Notes:}

The descriptive statistics refer to the weighted sample. Detailed descriptive statistics relative to workers' sectoral affiliation (Nace 2-digit), their occupation (ISCO 2-digit), the geographical distribution of establishments and the level of collective bargaining are available upon request.

*White-collar occupations include the following categories of the 2-digit International Standard Classification of Occupations (ISCO): (12) corporate managers, (21) physical, mathematical and engineering science professionals, (22) life science and health professionals, (24) other professionals, (31) physical and engineering science associate professionals, (32) life science and health associate professionals, (34) other associate professionals, (41) office clerks, (42) customer service clerks, (51) personal and protective services workers, and (52) models, salespersons and demonstrators. 
Table A.II. Regression results controlling only for human capital

\begin{tabular}{|c|c|c|c|c|c|c|c|c|c|c|c|c|}
\hline \multirow[t]{2}{*}{$\begin{array}{l}\text { dependent variable: individual } \\
\text { gross hourly wage (log) }\end{array}$} & \multicolumn{2}{|c|}{ Belgium } & \multicolumn{2}{|c|}{ Denmark } & \multicolumn{2}{|c|}{ Spain } & \multicolumn{2}{|c|}{ Italy } & \multicolumn{2}{|c|}{ Ireland } & \multicolumn{2}{|c|}{ United Kingdom } \\
\hline & part-time & full-time & part-time & full-time & part-time & full-time & part-time & full-time & part-time & full-time & part-time & full-time \\
\hline intercept & $\begin{array}{c}5.442^{* * * *} \\
(0.076)\end{array}$ & $\begin{array}{c}5.459^{* * *} \\
(0.007)\end{array}$ & $\begin{array}{c}4.23 * * * \\
(0.015)\end{array}$ & $\begin{array}{c}4.097 * * * \\
(0.005)\end{array}$ & $\begin{array}{c}6.101 * * * \\
(0.091)\end{array}$ & $\begin{array}{c}6.206^{* * *} \\
(0.011)\end{array}$ & $\begin{array}{c}2.321^{* * *} \\
(0.114)\end{array}$ & $\begin{array}{c}2.064 * * * \\
(0.015)\end{array}$ & $\begin{array}{c}0.667 * * * \\
(0.115)\end{array}$ & $\begin{array}{c}1.044^{* * *} \\
(0.019)\end{array}$ & $\begin{array}{c}1.110^{* * *} \\
(0.056)\end{array}$ & $\begin{array}{c}1.394^{* * *} \\
(0.009)\end{array}$ \\
\hline education: & & & & & & & & & & & & \\
\hline primary or no & reference & reference & reference & reference & reference & reference & reference & reference & reference & reference & reference & reference \\
\hline lower secondary & $\begin{array}{c}0.198^{* * *} \\
(0.057)\end{array}$ & $\begin{array}{c}0.124 * * * \\
(0.004)\end{array}$ & $\begin{array}{c}-0.089 * * * \\
(0.013)\end{array}$ & $\begin{array}{c}0.082^{* * *} \\
(0.004)\end{array}$ & $\begin{array}{c}0.063 \\
(0.045)\end{array}$ & $\begin{array}{c}0.053^{* * *} \\
(0.004)\end{array}$ & $\begin{array}{c}0.011 \\
(0.054)\end{array}$ & $\begin{array}{c}0.128^{* * *} \\
(0.010)\end{array}$ & $\begin{array}{c}0.165 \\
(0.110)\end{array}$ & $\begin{array}{c}0.203^{* * *} \\
(0.014)\end{array}$ & $\begin{array}{c}0.156^{* * *} \\
(0.041)\end{array}$ & $\begin{array}{c}0.155^{* * *} \\
(0.006)\end{array}$ \\
\hline upper secondary & $\begin{array}{c}0.217 * * * \\
(0.054)\end{array}$ & $\begin{array}{c}0.284 * * * \\
(0.004)\end{array}$ & $\begin{array}{c}0.108^{* * *} \\
(0.012)\end{array}$ & $\begin{array}{c}0.308^{* * *} \\
(0.003)\end{array}$ & $\begin{array}{c}0.145 * * * \\
(0.058)\end{array}$ & $\begin{array}{c}0.333^{* * *} \\
(0.006)\end{array}$ & $\begin{array}{c}0.201 * * \\
(0.099)\end{array}$ & $\begin{array}{c}0.427 * * * \\
(0.012)\end{array}$ & $\begin{array}{c}0.267^{* *} \\
(0.112)\end{array}$ & $\begin{array}{c}0.377 * * * \\
(0.015)\end{array}$ & $\begin{array}{c}0.144^{* * *} \\
(0.046)\end{array}$ & $\begin{array}{c}0.280^{* * *} \\
(0.006)\end{array}$ \\
\hline $\begin{array}{l}\text { higher non university short type } \\
\text { higher artistic training }\end{array}$ & $\begin{array}{c}0.406^{* * *} \\
(0.075)\end{array}$ & $\begin{array}{c}0.519 * * * \\
(0.005)\end{array}$ & $\begin{array}{c}0.164 * * * \\
(0.024)\end{array}$ & $\begin{array}{c}0.474 * * * \\
(0.004)\end{array}$ & $\begin{array}{c}0.321 * * * \\
(0.122)\end{array}$ & $\begin{array}{c}0.407^{* * *} \\
(0.008)\end{array}$ & $\begin{array}{c}0.652^{* * *} \\
(0.085)\end{array}$ & $\begin{array}{c}0.595^{* * *} \\
(0.039)\end{array}$ & $\begin{array}{c}0.457 * * * \\
(0.122)\end{array}$ & $\begin{array}{c}0.710^{* * *} \\
(0.017)\end{array}$ & $\begin{array}{c}0.268^{* *} \\
(0.120)\end{array}$ & $\begin{array}{c}0.552^{* * * *} \\
(0.009)\end{array}$ \\
\hline university and $n$ & & & & & & & & & & & & \\
\hline higher education, long type & $\begin{array}{c}0.636^{* * *} \\
(0.101)\end{array}$ & $\begin{array}{c}0.840^{* * *} \\
(0.006)\end{array}$ & $\begin{array}{c}0.391 * * * \\
(0,035)\end{array}$ & $\begin{array}{c}0.731 * * * \\
(0.004)\end{array}$ & $\begin{array}{c}0.759 * * * \\
(0.069)\end{array}$ & $\begin{array}{c}0.793^{* * *} \\
(0.010)\end{array}$ & $\begin{array}{c}0.441 * * * \\
(0.116)\end{array}$ & $\begin{array}{c}0.826^{* * *} \\
(0.024)\end{array}$ & $\begin{array}{c}0.541 * * * \\
(0.153)\end{array}$ & $\begin{array}{c}1.020^{* * *} \\
(0.019)\end{array}$ & $\begin{array}{c}0.481 * * * \\
(0.093)\end{array}$ & $\begin{array}{c}0.770^{* * *} \\
(0.009)\end{array}$ \\
\hline post $-\xi$ & $\begin{array}{c}1.364^{* * *} \\
(0.161)\end{array}$ & $\begin{array}{c}1.019^{* * *} \\
(0.024)\end{array}$ & $\begin{array}{c}0.395^{* * *} \\
(0.049)\end{array}$ & $\begin{array}{c}0.867 * * * \\
(0.005)\end{array}$ & $\begin{array}{c}1.076^{* * *} \\
(0.298)\end{array}$ & $\begin{array}{c}1.079^{* * *} \\
(0.083)\end{array}$ & & $\begin{array}{c}0.960^{* * *} \\
(0.105)\end{array}$ & $\begin{array}{c}1.155^{* * *} \\
(0.135)\end{array}$ & $\begin{array}{c}1.214 * * * \\
(0.032)\end{array}$ & $\begin{array}{c}0.777 \\
(0.557)\end{array}$ & $\begin{array}{c}0.922^{* * *} \\
(0.017)\end{array}$ \\
\hline & & & & & & & & & & & & \\
\hline simple & $\begin{array}{c}0.033^{* * *} \\
(0.011)\end{array}$ & $\begin{array}{c}0.032^{* * *} \\
(0.001)\end{array}$ & $\begin{array}{c}0.058^{* * *} \\
(0.002)\end{array}$ & $\begin{array}{c}0.047 * * * \\
(0.001)\end{array}$ & $\begin{array}{c}0.036 * * \\
(0.017)\end{array}$ & $\begin{array}{c}0.025^{* * *} \\
(0.002)\end{array}$ & $\begin{array}{c}0.006 \\
(0.015)\end{array}$ & $\begin{array}{c}0.028^{* * *} \\
(0.001)\end{array}$ & $\begin{array}{c}0.062 * * * \\
(0.013)\end{array}$ & $\begin{array}{c}0.045^{* * *} \\
(0.002)\end{array}$ & $\begin{array}{c}0.041 * * * \\
(0.007)\end{array}$ & $\begin{array}{c}0.050^{* * *} \\
(0.001)\end{array}$ \\
\hline squared $/ 10^{2}$ & $\begin{array}{l}-0.001 * \\
(0.001)\end{array}$ & $\begin{array}{c}-0.001 * * * \\
(0.000)\end{array}$ & $\begin{array}{c}-0.002^{* * *} \\
(0.000)\end{array}$ & $\begin{array}{c}-0.002 * * * \\
(0.000)\end{array}$ & $\begin{array}{c}-0.002^{* *} \\
(0.001)\end{array}$ & $\begin{array}{c}-0.001 * * * \\
(0.000)\end{array}$ & $\begin{array}{l}-0.001 \\
(0.001)\end{array}$ & $\begin{array}{c}-0.001 * * * \\
(0.000)\end{array}$ & $\begin{array}{c}-0.002^{* * *} \\
(0.001)\end{array}$ & $\begin{array}{c}-0.002^{* * *} \\
(0.000)\end{array}$ & $\begin{array}{c}-0.001 * * * \\
(0.000)\end{array}$ & $\begin{array}{c}-0.002^{* * *} \\
(0.000)\end{array}$ \\
\hline cubed $/ 10^{4}$ & $\begin{array}{c}0.000 \\
(0.000)\end{array}$ & $\begin{array}{c}0.000^{* * *} \\
(0.000)\end{array}$ & $\begin{array}{c}0.000^{* * *} \\
(0.000)\end{array}$ & $\begin{array}{c}0.000^{* * *} \\
(0.000)\end{array}$ & $\begin{array}{l}0.000 * * \\
(0.000)\end{array}$ & $\begin{array}{c}0.000^{* * *} \\
(0.000)\end{array}$ & $\begin{array}{c}0.000 \\
(0.000)\end{array}$ & $\begin{array}{c}0.000^{* * *} \\
(0.000)\end{array}$ & $\begin{array}{c}0.000^{* *} \\
(0.000)\end{array}$ & $\begin{array}{c}0.000 * * * \\
(0.000)\end{array}$ & $\begin{array}{c}0.000^{* * *} \\
(0.000)\end{array}$ & $\begin{array}{c}0.000^{* * *} \\
(0.000)\end{array}$ \\
\hline seniority in & & & & & & & & & & & & \\
\hline simple & $\begin{array}{c}0.025^{* *} \\
(0.012)\end{array}$ & $\begin{array}{c}0.035^{* * *} \\
(0.001)\end{array}$ & $\begin{array}{c}0.019 * * * \\
(0.002)\end{array}$ & $\begin{array}{c}0.015^{* * *} \\
(0.001)\end{array}$ & $\begin{array}{c}0.0765^{* * *} \\
(0.017)\end{array}$ & $\begin{array}{c}0.059^{* * *} \\
(0.001)\end{array}$ & $\begin{array}{c}0.012 \\
(0.026)\end{array}$ & $\begin{array}{c}0.032^{* * *} \\
(0.002)\end{array}$ & $\begin{array}{c}0.086^{* * *} \\
(0.017)\end{array}$ & $\begin{array}{c}0.062^{* * *} \\
(0.002)\end{array}$ & $\begin{array}{c}0.070^{* * *} \\
(0.023)\end{array}$ & $\begin{array}{c}0.049 * * * \\
(0.002)\end{array}$ \\
\hline squared $/ 10^{2}$ & $\begin{array}{c}0.000 \\
(0.001)\end{array}$ & $\begin{array}{c}-0.001 * * * \\
(0.000)\end{array}$ & $\begin{array}{c}-0.001^{* * *} \\
(0.000)\end{array}$ & $\begin{array}{c}-0.000 * * * \\
(0.000)\end{array}$ & $\begin{array}{l}-0.002 \\
(0.001)\end{array}$ & $\begin{array}{c}-0.002 * * * \\
(0.000)\end{array}$ & $\begin{array}{c}0.001 \\
(0.002)\end{array}$ & $\begin{array}{c}-0.001 * * * \\
(0.000)\end{array}$ & $\begin{array}{c}-0.005^{* * *} \\
(0.001)\end{array}$ & $\begin{array}{c}-0.002 * * * \\
(0.000)\end{array}$ & $\begin{array}{l}-0.004 \\
(0.004)\end{array}$ & $\begin{array}{c}-0.004^{* * *} \\
(0.000)\end{array}$ \\
\hline cubed $/ 10^{4}$ & $\begin{array}{r}-0.000 \\
(0.000) \\
\end{array}$ & $\begin{array}{c}0.000 * * * \\
(0.000) \\
\end{array}$ & $\begin{array}{c}0.000 * * * \\
(0.000)\end{array}$ & $\begin{array}{c}0.000 \\
(0.000) \\
\end{array}$ & $\begin{array}{c}0.000 \\
(0.000) \\
\end{array}$ & $\begin{array}{c}0.000 * * * \\
(0.000) \\
\end{array}$ & $\begin{array}{l}-0.000 \\
(0.000) \\
\end{array}$ & $\begin{array}{c}0.000^{* *} \\
(0.000) \\
\end{array}$ & $\begin{array}{c}0.000^{* * *} \\
(0.000) \\
\end{array}$ & $\begin{array}{c}0.000^{* * *} \\
(0.000) \\
\end{array}$ & $\begin{array}{c}0.000 \\
(0.000) \\
\end{array}$ & $\begin{array}{c}0.000^{* * * *} \\
(0.000) \\
\end{array}$ \\
\hline $\mathrm{R}^{2}$ adjusted & 0.254 & 0.485 & 0.272 & 0.385 & 0.436 & 0.396 & 0.160 & 0.435 & 0.397 & 0.435 & 0.137 & 0.261 \\
\hline F-test & $28 * * *$ & $3088^{* * *}$ & $269 * * *$ & $7621^{* * *}$ & $43^{* * *}$ & $2273^{* * *}$ & $565^{* * *}$ & $614^{* * *}$ & $42^{* * *}$ & $862 * * *$ & $13^{* * *}$ & $1326^{* * *}$ \\
\hline Number of observations & 711 & 56,568 & 12,257 & 189,345 & 1,317 & 125,161 & 506 & 66,983 & 489 & 19,717 & 1,169 & 46,381 \\
\hline
\end{tabular}

Notes: Part-time is defined as a range of weekly working hours between 15 and 29 and full-time corresponds to weekly working hours equal or above 30 . White (1980) heteroscedasticity consistent standard errors are reported within brackets. * statistically significant at the .10 level; ** at the 0.05 level; *** at the 0.1 level. 
Table A.III. Regression results with full set of control variables

\begin{tabular}{|c|c|c|c|c|c|c|c|c|c|c|c|c|}
\hline \multirow[t]{2}{*}{$\begin{array}{l}\text { dependent variable: individual gross } \\
\text { hourly wage }(\log )\end{array}$} & \multicolumn{2}{|c|}{ Belgium } & \multicolumn{2}{|c|}{ Denmark } & \multicolumn{2}{|c|}{ Spain } & \multicolumn{2}{|c|}{ Italy } & \multicolumn{2}{|c|}{ Ireland } & \multicolumn{2}{|c|}{ United Kingdom } \\
\hline & part-time & full-time & part-time & full-time & part-time & full-time & part-time & full-time & part-time & full-time & part-time & full-time \\
\hline intercept & $\begin{array}{c}5,657^{* * *} \\
(0,256)\end{array}$ & $\begin{array}{c}5,346^{* * *} \\
(0,019)\end{array}$ & $\begin{array}{c}4,350^{* * *} \\
(0,059)\end{array}$ & $\begin{array}{c}4,429 * * * \\
(0,013)\end{array}$ & $\begin{array}{c}6,118^{* * *} \\
(0,141)\end{array}$ & $\begin{array}{c}6,191 * * * \\
(0,022)\end{array}$ & $\begin{array}{c}2,509 * * * \\
(0,145)\end{array}$ & $\begin{array}{c}2,186^{* * *} \\
(0,028)\end{array}$ & $\begin{array}{c}0,634 * * * \\
(0,183)\end{array}$ & $\begin{array}{c}0,988^{* * *} \\
(0,035)\end{array}$ & $\begin{array}{c}1,206^{* * *} \\
(0,104)\end{array}$ & $\begin{array}{c}1,082^{* * *} \\
(0,023)\end{array}$ \\
\hline education: & & & & & & & & & & & & \\
\hline primary or no degree & reference & reference & reference & reference & reference & reference & reference & reference & reference & reference & reference & reference \\
\hline lower secondary & $\begin{array}{c}0,174 * * * \\
(0,056)\end{array}$ & $\begin{array}{c}0,075^{* * *} \\
(0,003)\end{array}$ & $\begin{array}{c}-0,056^{* * *} \\
(0,012)\end{array}$ & $\begin{array}{c}0,062^{* * *} \\
(0,003)\end{array}$ & $\begin{array}{c}0.034 \\
(0,042)\end{array}$ & $\begin{array}{c}0,028^{* * *} \\
(0,004)\end{array}$ & $\begin{array}{c}0.022 \\
(0,060)\end{array}$ & $\begin{array}{c}0,052^{* * *} \\
(0,007)\end{array}$ & $\begin{array}{c}0.148 \\
(0,102)\end{array}$ & $\begin{array}{c}0,106^{* * *} \\
(0,013)\end{array}$ & $\begin{array}{c}0.046 \\
(0,039)\end{array}$ & $\begin{array}{c}0,031 * * * \\
(0,005)\end{array}$ \\
\hline upper secondary & $\begin{array}{c}0,195^{* * *} \\
(0,059)\end{array}$ & $\begin{array}{c}0,161 * * * \\
(0,004)\end{array}$ & $\begin{array}{c}0,049 * * * \\
(0,011)\end{array}$ & $\begin{array}{c}0,099 * * * \\
(0,002)\end{array}$ & $\begin{array}{c}0.029 \\
(0,057)\end{array}$ & $\begin{array}{c}0,147 * * * \\
(0,006)\end{array}$ & $\begin{array}{l}-0,054 \\
(0,079)\end{array}$ & $\begin{array}{c}0,159 * * * \\
(0,009)\end{array}$ & $\begin{array}{l}0,178^{*} \\
(0,105)\end{array}$ & $\begin{array}{c}0,212^{* * *} \\
(0,013)\end{array}$ & $\begin{array}{c}0.05 \\
(0,038)\end{array}$ & $\begin{array}{c}0,090 * * * \\
(0,004)\end{array}$ \\
\hline $\begin{array}{l}\text { higher non university short type, higher } \\
\text { artistic training }\end{array}$ & $\begin{array}{c}0,242^{* * *} \\
(0,075)\end{array}$ & $\begin{array}{c}0,240^{* * *} \\
(0,005)\end{array}$ & $\begin{array}{c}0,086^{* * *} \\
(0,020)\end{array}$ & $\begin{array}{c}0,149 * * * \\
(0,004)\end{array}$ & $\begin{array}{c}0.088 \\
(0,091)\end{array}$ & $\begin{array}{c}0,191 * * * \\
(0,008)\end{array}$ & $\begin{array}{c}0.131 \\
(0,121)\end{array}$ & $\begin{array}{c}0,115^{* * *} \\
(0,032)\end{array}$ & $\begin{array}{c}0,482^{* * *} \\
(0,117)\end{array}$ & $\begin{array}{c}0,340 * * * \\
(0,016)\end{array}$ & $\begin{array}{l}-0,041 \\
(0,108)\end{array}$ & $\begin{array}{c}0,153^{* * *} \\
(0,008)\end{array}$ \\
\hline $\begin{array}{l}\text { university and non university higher } \\
\text { education, long type }\end{array}$ & $\begin{array}{c}0,370 * * * \\
(0,117)\end{array}$ & $\begin{array}{c}0,432 * * * \\
(0,007)\end{array}$ & $\begin{array}{c}0,146^{* * *} \\
(0,030)\end{array}$ & $\begin{array}{c}0,271 * * * \\
(0,004)\end{array}$ & $\begin{array}{c}0,382^{* * *} \\
(0,113)\end{array}$ & $\begin{array}{c}0,378^{* * *} \\
(0,013)\end{array}$ & $\begin{array}{l}-0,028 \\
(0,117)\end{array}$ & $\begin{array}{c}0,230 * * * \\
(0,019)\end{array}$ & $\begin{array}{c}0,478^{* * *} \\
(0,155)\end{array}$ & $\begin{array}{c}0,485^{* * *} \\
(0,021)\end{array}$ & $\begin{array}{c}0.098 \\
(0,072)\end{array}$ & $\begin{array}{c}0,234^{* * *} \\
(0,008)\end{array}$ \\
\hline post-graduate & $\begin{array}{c}0,948^{* * *} \\
(0,207)\end{array}$ & $\begin{array}{c}0,559 * * * \\
(0,020)\end{array}$ & $\begin{array}{c}0,128^{* * *} \\
(0,039)\end{array}$ & $\begin{array}{c}0,345^{* * *} \\
(0,005)\end{array}$ & $\begin{array}{c}0,752^{* * *} \\
(0,210)\end{array}$ & $\begin{array}{c}0,599 * * * \\
(0,071)\end{array}$ & na & $\begin{array}{c}0,411 * * * \\
(0,042)\end{array}$ & $\begin{array}{c}1,076^{* * *} \\
(0,253)\end{array}$ & $\begin{array}{c}0,631 * * * \\
(0,031)\end{array}$ & $\begin{array}{l}-0,076 \\
(0,461)\end{array}$ & $\begin{array}{c}0,317^{* * *} \\
(0,016)\end{array}$ \\
\hline prior potential experience & & & & & & & & & & & & \\
\hline simple & $\begin{array}{l}0,022^{*} \\
(0,012)\end{array}$ & $\begin{array}{c}0,019 * * * \\
(0,001)\end{array}$ & $\begin{array}{c}0,030 * * * \\
(0,002)\end{array}$ & $\begin{array}{c}0,013 * * * \\
(0,000)\end{array}$ & $\begin{array}{c}0,027^{* *} \\
(0,013)\end{array}$ & $\begin{array}{c}0,020^{* * *} \\
(0,002)\end{array}$ & $\begin{array}{c}0.001 \\
(0,007)\end{array}$ & $\begin{array}{c}0,016^{* * *} \\
(0,001)\end{array}$ & $\begin{array}{c}0,041 * * * \\
(0,013)\end{array}$ & $\begin{array}{c}0,033 * * * \\
(0,002)\end{array}$ & $\begin{array}{c}0,020^{* * *} \\
(0,007)\end{array}$ & $\begin{array}{c}0,022 * * * \\
(0,001)\end{array}$ \\
\hline squared $/ 10^{2}$ & $\begin{array}{l}-0,001 \\
(0,001)\end{array}$ & $\begin{array}{c}-0,001 * * * \\
(0,000)\end{array}$ & $\begin{array}{c}-0,001 * * * \\
(0,000)\end{array}$ & $\begin{array}{c}-0,000^{* * *} \\
(0,000)\end{array}$ & $\begin{array}{c}-0,002^{* *} \\
(0,001)\end{array}$ & $\begin{array}{c}-0,001 * * * \\
(0,000)\end{array}$ & $\begin{array}{c}0.000 \\
(0,000)\end{array}$ & $\begin{array}{c}-0,000^{* * *} \\
(0,000)\end{array}$ & $\begin{array}{c}-0,002^{* *} \\
(0,001)\end{array}$ & $\begin{array}{c}-0,001 * * * \\
(0,000)\end{array}$ & $\begin{array}{c}-0,001^{* *} \\
(0,000)\end{array}$ & $\begin{array}{c}-0,001 * * * \\
(0,000)\end{array}$ \\
\hline cubed $/ 10^{4}$ & $\begin{array}{c}0.000 \\
(0,000)\end{array}$ & $\begin{array}{c}0,000^{* * *} \\
(0,000)\end{array}$ & $\begin{array}{c}0,000^{* * *} \\
(0,000)\end{array}$ & $\begin{array}{c}0,000^{* * *} \\
(0,000)\end{array}$ & $\begin{array}{c}0,000^{* * *} \\
(0,000)\end{array}$ & $\begin{array}{c}0,000^{* * *} \\
(0,000)\end{array}$ & $\begin{array}{l}-0,000 \\
(0,000)\end{array}$ & $\begin{array}{c}0,000^{* * *} \\
(0,000)\end{array}$ & $\begin{array}{l}0,000^{*} \\
(0,000)\end{array}$ & $\begin{array}{c}0,000^{* * *} \\
(0,000)\end{array}$ & $\begin{array}{c}0,000 \\
(0,000)\end{array}$ & $\begin{array}{c}0,000^{* * *} \\
(0,000)\end{array}$ \\
\hline seniority in the company: & & & & & & & & & & & & \\
\hline simple & $\begin{array}{c}0.012 \\
(0,012)\end{array}$ & $\begin{array}{c}0,023^{* * *} \\
(0,001)\end{array}$ & $\begin{array}{c}0,018^{* * *} \\
(0,002)\end{array}$ & $\begin{array}{c}0,017^{* * *} \\
(0,001)\end{array}$ & $\begin{array}{c}0,062^{* * *} \\
(0,015)\end{array}$ & $\begin{array}{c}0,026^{* * *} \\
(0,002)\end{array}$ & $\begin{array}{c}0.002 \\
(0,013)\end{array}$ & $\begin{array}{c}0,016^{* * *} \\
(0,002)\end{array}$ & $\begin{array}{c}0,107 * * * \\
(0,020)\end{array}$ & $\begin{array}{c}0,048^{* * *} \\
(0,002)\end{array}$ & $\begin{array}{l}0,038^{*} \\
(0,021)\end{array}$ & $\begin{array}{c}0,035^{* * *} \\
(0,002)\end{array}$ \\
\hline squared $/ 10^{2}$ & $\begin{array}{c}0.000 \\
(0,001)\end{array}$ & $\begin{array}{c}-0,001 * * * \\
(0,000)\end{array}$ & $\begin{array}{c}-0,001 * * * \\
(0,000)\end{array}$ & $\begin{array}{c}-0,001 * * * \\
(0,000)\end{array}$ & $\begin{array}{l}-0,002 \\
(0,001)\end{array}$ & $\begin{array}{c}-0,001 * * * \\
(0,000)\end{array}$ & $\begin{array}{c}0.000 \\
(0,001)\end{array}$ & $\begin{array}{c}-0,000^{* *} \\
(0,000)\end{array}$ & $\begin{array}{c}-0,007 * * * \\
(0,002)\end{array}$ & $\begin{array}{c}-0,001 * * * \\
(0,000)\end{array}$ & $\begin{array}{l}-0,002 \\
(0,004)\end{array}$ & $\begin{array}{c}-0,002^{* * *} \\
(0,000)\end{array}$ \\
\hline cubed $/ 10^{4}$ & $\begin{array}{l}-0,000 \\
(0,000)\end{array}$ & $\begin{array}{c}0,000^{* * *} \\
(0,000)\end{array}$ & $\begin{array}{c}0,000 * * * \\
(0,000)\end{array}$ & $\begin{array}{c}0,000^{* * *} \\
(0,000)\end{array}$ & $\begin{array}{c}0.000 \\
(0,000)\end{array}$ & $\begin{array}{c}0,000 * * * \\
(0,000)\end{array}$ & $\begin{array}{c}0.000 \\
(0,000)\end{array}$ & $\begin{array}{c}0,000 \\
(0,000)\end{array}$ & $\begin{array}{c}0,000^{* * *} \\
(0,000)\end{array}$ & $\begin{array}{c}0,000^{* * *} \\
(0,000)\end{array}$ & $\begin{array}{c}0.000 \\
(0,000)\end{array}$ & $\begin{array}{c}0,000^{* * *} \\
(0,000)\end{array}$ \\
\hline
\end{tabular}


Table A.III. Regression results with full set of control variables (continued)

\begin{tabular}{|c|c|c|c|c|c|c|c|c|c|c|c|c|}
\hline overtime paid (yes) & $\begin{array}{c}0.060 \\
(0,073)\end{array}$ & $\begin{array}{c}0,010 * * * \\
(0,003)\end{array}$ & $\begin{array}{c}-0,038^{* * *} \\
(0,006)\end{array}$ & $\begin{array}{c}-0,024 * * * \\
(0,001)\end{array}$ & $\begin{array}{c}0,324 * * * \\
(0,059)\end{array}$ & $\begin{array}{c}0,146^{* * *} \\
(0,004)\end{array}$ & $\begin{array}{l}0,111 * * \\
(0,051)\end{array}$ & $\begin{array}{l}-0,007 \\
(0,005)\end{array}$ & $\begin{array}{c}0.091 \\
(0,071)\end{array}$ & $\begin{array}{c}0.007 \\
(0,006)\end{array}$ & $\begin{array}{l}0,057^{*} \\
(0,030)\end{array}$ & $\begin{array}{c}-0,052^{* * *} \\
(0,003)\end{array}$ \\
\hline $\begin{array}{l}\text { bonus for shift work, night work and/or } \\
\text { weekend work (yes) }\end{array}$ & $\begin{array}{l}0,088^{*} \\
(0,049)\end{array}$ & $\begin{array}{c}0,062^{* * *} \\
(0,003)\end{array}$ & $\begin{array}{c}0,043^{* * *} \\
(0,006)\end{array}$ & $\begin{array}{c}0,022^{* * *} \\
(0,001)\end{array}$ & $\begin{array}{c}0,129 * * * \\
(0,040)\end{array}$ & $\begin{array}{c}0,075^{* * *} \\
(0,005)\end{array}$ & $\begin{array}{c}0.023 \\
(0,036)\end{array}$ & $\begin{array}{c}0,068 * * * \\
(0,007)\end{array}$ & $\begin{array}{c}0.158 \\
(0,106)\end{array}$ & $\begin{array}{c}0,137 * * * \\
(0,009)\end{array}$ & $\begin{array}{c}0,202 * * * \\
(0,035)\end{array}$ & $\begin{array}{c}0,097 * * * \\
(0,004)\end{array}$ \\
\hline $\begin{array}{l}\text { occupation ( } 20 \text { dummies) } \\
\text { contract: }\end{array}$ & $\begin{array}{c}0,223^{* * *} \\
(0,060) \\
\text { yes }\end{array}$ & $\begin{array}{c}0,119 * * * \\
(0,004) \\
\text { yes }\end{array}$ & $\begin{array}{c}0,186^{* * *} \\
(0,055) \\
\text { yes }\end{array}$ & $\begin{array}{c}0,200 * * * \\
(0,002) \\
\text { yes }\end{array}$ & yes & yes & $\begin{array}{c}0,230 * * * \\
(0,045) \\
\text { yes }\end{array}$ & $\begin{array}{c}0,147 * * * \\
(0,008) \\
\text { yes }\end{array}$ & $\begin{array}{c}0.007 \\
(0,060) \\
\text { yes }\end{array}$ & $\begin{array}{c}0,145^{* * *} \\
(0,009) \\
\text { yes }\end{array}$ & $\begin{array}{c}0,236^{*} \\
(0,123) \\
\text { yes }\end{array}$ & $\begin{array}{c}0,135^{* * *} \\
(0,005) \\
\text { yes }\end{array}$ \\
\hline $\begin{array}{l}\text { unlimited-term employment contract } \\
\text { limited-term employment contract }\end{array}$ & $\begin{array}{c}\text { reference } \\
-0,123 \\
(0,100)\end{array}$ & $\begin{array}{c}\text { reference } \\
-0,022^{* * *} \\
(0,007)\end{array}$ & $\begin{array}{c}\text { reference } \\
-0,012 \\
(0,017)\end{array}$ & $\begin{array}{c}\text { reference } \\
-0,046 * * * \\
(0,007)\end{array}$ & $\begin{array}{c}\text { reference } \\
-0,003 \\
(0,040)\end{array}$ & $\begin{array}{c}\text { reference } \\
-0,109 * * * \\
(0,006)\end{array}$ & $\begin{array}{c}\text { reference } \\
-0,020 \\
(0,056)\end{array}$ & $\begin{array}{c}\text { reference } \\
-0,048^{* * *} \\
(0,014)\end{array}$ & $\begin{array}{c}\text { reference } \\
0,179 * * \\
(0,084)\end{array}$ & $\begin{array}{c}\text { reference } \\
-0,071 * * * \\
(0,015)\end{array}$ & $\begin{array}{c}\text { reference } \\
-0,017 \\
(0,040)\end{array}$ & $\begin{array}{c}\text { reference } \\
0.004 \\
(0,007)\end{array}$ \\
\hline other employment contract & $\begin{array}{c}-0,266^{* * *} \\
(0,067)\end{array}$ & $\begin{array}{c}-0,172 * * * \\
(0,054)\end{array}$ & $\begin{array}{c}-0,470 * * * \\
(0,015)\end{array}$ & $\begin{array}{c}-0,681 * * * \\
(0,004)\end{array}$ & $\begin{array}{l}-0,118 \\
(0,151)\end{array}$ & $\begin{array}{c}-0,478^{* * *} \\
(0,024)\end{array}$ & $\begin{array}{l}-0,264 * \\
(0,154)\end{array}$ & $\begin{array}{c}-0,145^{* * *} \\
(0,015)\end{array}$ & $\begin{array}{l}-0,038 \\
(0,078)\end{array}$ & $\begin{array}{c}-0,271 * * * \\
(0,024)\end{array}$ & $\begin{array}{l}-0,023 \\
(0,051)\end{array}$ & $\begin{array}{c}-0,488^{* * *} \\
(0,014)\end{array}$ \\
\hline $\begin{array}{l}\text { region } \\
\text { establishment's economic and financial } \\
\text { control: }\end{array}$ & yes & yes & na & na & yes & yes & yes & yes & na & na & yes & yes \\
\hline $\begin{array}{l}\text { more than } 50 \% \text { privately owned } \\
\text { fully state owned }\end{array}$ & $\begin{array}{c}\text { reference } \\
0.029 \\
(0,133)\end{array}$ & $\begin{array}{c}\text { reference } \\
-0,225 * * * \\
(0,015)\end{array}$ & $\begin{array}{c}\text { reference } \\
-\end{array}$ & $\begin{array}{c}\text { reference } \\
-\end{array}$ & $\begin{array}{c}\text { reference } \\
0,237 * * * \\
(0,081)\end{array}$ & $\begin{array}{c}\text { reference } \\
-0,023^{* * *} \\
(0,008)\end{array}$ & $\begin{array}{l}\text { na } \\
\text { na }\end{array}$ & $\begin{array}{l}\text { na } \\
\text { na }\end{array}$ & $\begin{array}{l}\text { na } \\
\text { na }\end{array}$ & $\begin{array}{c}\text { reference } \\
-0,076^{* * *} \\
(0,018)\end{array}$ & $\begin{array}{l}\text { reference } \\
-0,086 \\
(0,106)\end{array}$ & $\begin{array}{c}\text { reference } \\
0.005 \\
(0,009)\end{array}$ \\
\hline more than $50 \%$ state owned & $\begin{array}{l}-0,019 \\
(0,105)\end{array}$ & $\begin{array}{c}-0,013^{* *} \\
(0,006)\end{array}$ & $\begin{array}{l}-0,069 \\
(0,066)\end{array}$ & $\begin{array}{c}0,089 * * * \\
(0,008)\end{array}$ & $\begin{array}{l}-0,051 \\
(0,125)\end{array}$ & $\begin{array}{l}-0,005 \\
(0,013)\end{array}$ & na & na & na & $\begin{array}{c}0.095 \\
(0,067)\end{array}$ & - & - \\
\hline other & $\begin{array}{l}-0,038 \\
(0,045)\end{array}$ & $\begin{array}{c}-0,024 * * * \\
(0,004)\end{array}$ & - & - & $\begin{array}{l}-0,118 \\
(0,130)\end{array}$ & $\begin{array}{c}0,080 * * * \\
(0,017)\end{array}$ & na & na & na & na & - & - \\
\hline level of wage barg & yes & yes & yes & yes & yes & yes & yes & yes & yes & yes & yes & yes \\
\hline size of the establishment (log) & $\begin{array}{l}0,041 * * \\
(0,018)\end{array}$ & $\begin{array}{c}0,030 * * * \\
(0,001)\end{array}$ & $\begin{array}{c}0,009 * * * \\
(0,002)\end{array}$ & $\begin{array}{c}0,013 * * * \\
(0,000)\end{array}$ & $\begin{array}{c}0,033^{* *} \\
(0,013)\end{array}$ & $\begin{array}{c}0,044 * * * \\
(0,002)\end{array}$ & $\begin{array}{l}-0,009 \\
(0,014)\end{array}$ & $\begin{array}{c}0,030^{* * *} \\
(0,002)\end{array}$ & $\begin{array}{c}0,047 * * * \\
(0,011)\end{array}$ & $\begin{array}{c}0,039 * * * \\
(0,002)\end{array}$ & $\begin{array}{c}0.002 \\
(0,006)\end{array}$ & $\begin{array}{c}0,021 * * * \\
(0,001)\end{array}$ \\
\hline industry effects (42 dummies) & yes & yes & yes & yes & yes & yes & yes & yes & yes & yes & yes & yes \\
\hline $\mathrm{R}^{2}$ adjusted & 0.383 & 0.683 & 0.446 & 0.668 & 0.599 & 0.551 & 0.756 & 0.687 & 0.517 & 0.624 & 0.35 & 0.586 \\
\hline F-test & $750 * * *$ & $1014 * * *$ & $1152 * * *$ & $3688 * * *$ & $20 * * *$ & $877 * * *$ & $47301385^{* *}$ & $314 * * *$ & $558 * * *$ & $321 * * *$ & $16^{* * *}$ & $662^{* * *}$ \\
\hline Number of observations & 711 & 56,568 & 12,257 & 189,345 & 1,317 & 125,161 & 506 & 66,983 & 489 & 19,717 & 1,169 & 46,381 \\
\hline
\end{tabular}

Notes: Part-time is defined as a range of weekly working hours between 15 and 29 and full-time corresponds to weekly working hours equal or above 30. White (1980) heteroscedasticity consistent standard errors are reported within brackets. * statistically significant at the .10 level; ** at the 0.05 level; *** at the 0.1 level. The variable "region" is not available for Ireland or Denmark. It corresponds to 2 dummies for Belgium, 6 for Spain, 10 for Italy, and 9 for the UK. The variable "size of the 
establishment” refers to the number of workers employed. As regards the level of wage bargaining, for Belgium and Denmark, we add 2 dummies, i.e. for establishments covered by: (i) an enterprise collective agreement, and (ii) other pay-setting arrangements. For Ireland, we add 1 dummy, i.e. for establishments covered by an enterprise collective agreement. For Italy, we add 3 dummies, i.e. for establishments covered by: (i) an enterprise collective agreement, (ii) an establishment collective agreement, and (iii) other pay-setting arrangements. For Spain, we add 4 dummies, i.e. for establishments covered by: (i) an above-enterprise collective agreement (provincial/regional level or within sectors at the provincial/regional level), (ii) an enterprise collective agreement, (iii) an establishment collective agreement, and (iv) other pay-setting arrangements. In all countries the reference group that was left out is composed of establishments solely covered by national and/or sector-level collective agreements. 